\title{
Symbolic Thickening of Public Culture and the Rise of Right-Wing Populism in Poland
}

Forthcoming in East European Politics and Societies: and Cultures in 2019

Marta Kotwas

University College London

Jan Kubik

Rutgers University \& University College London

\section{Rosary to the Borders}

On 7 October 2017 about one million ${ }^{1}$ Polish Catholics joined in a collective prayer under the slogan "Rosary to the Borders." They first congregated in around 320 churches in 22 dioceses and then moved to about 4,000 "prayer zones" located along the full length of the Polish border, including the beaches of the Baltic Sea and international airports (Fig. 1). According to Maciej Bodasiński and Lech Dokowicz of the Solo Dios Basta association, the event's primary organizer, the intention was to "gather as many Catholics as possible to surround Poland's borders and pray the Rosary to protect their homeland, Europe, and the world at a time when the nefarious influence of secularism is growing and violent conflicts rage in many places."2 The event was initiated by lay Catholics, but in late August it gained official support from the heads of the Polish Church. ${ }^{3}$ For example, Archbishop Marek Jędraszewski ${ }^{4}$ of Kraków told

${ }^{1}$ C. Giangravè, "Catholic 'Rosary to the Border' event highlights immigration concerns in Poland," Crux, 12 October 2017, https://cruxnow.com/global-church/2017/10/12/catholic-rosary-borderevent-highlights-immigration-concerns-poland/ (accessed 17 October 2017).

${ }^{2}$ F. Mazurczak, "Poland Prays: Hundreds of Thousands Participate in Rosary," National Catholic Register, 10 October 2017, http://www.ncregister.com/daily-news/poland-prays-hundreds-of-thousandsparticipate-in-rosary-to-the-borders (accessed 17 October 2017). The event was organized on the Catholic holiday of Our Lady of the Rosary, which in 2017 coincided with the $100^{\text {th }}$ anniversary of the Fatima apparitions and the $300^{\text {th }}$ anniversary of the canonical coronation of the most holy icon of Polish Catholicism, the Black Madonna of Częstochowa.

3 ““'Różaniec do granic.' Abp Stanisław Gądecki: celem jest modlitwa o pokój,” Teologia Polityczna, 7 October 2017, http://www.teologiapolityczna.pl/dzisiaj-rozaniec-do-granic-abp-gadeckicelem-jest-modlitwa-o-pokoj (accessed 17 October 2017). 
participants that the massive prayer was a message "to other European nations so that they understand that it's necessary to return to Christian roots so that Europe may remain Europe." The event was also advertised on TV and endorsed on Twitter by a number of prominent politicians of the governing Law and Justice party, including the Prime Minister. ${ }^{6}$

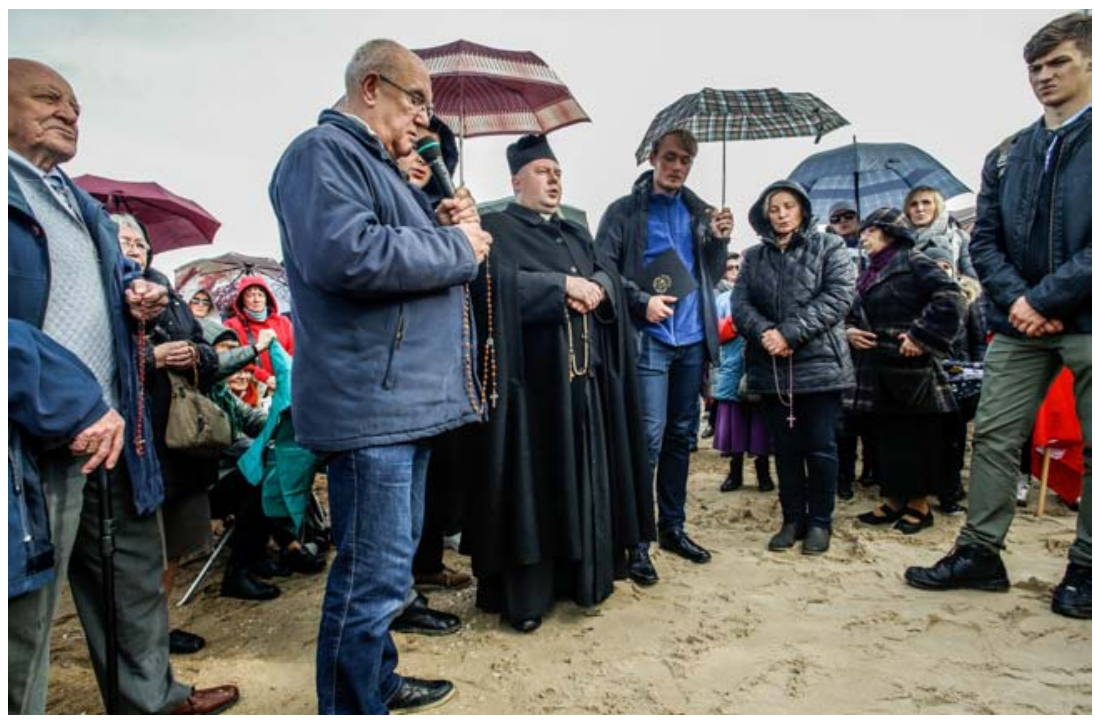

[Fig. 1. "Rosary to the Borders" on the beach in Gdańsk Jelitkowo, 7 October 2017. Copyright Karolina Misztal / REPORTER.]

While the official event website and the website of the Polish Bishops' Conference emphasized the redemptive dimension of this massive Rosary prayer, the fact that it was organized on the feast established to commemorate the Battle of Lepanto, when the Catholic

${ }^{4}$ In 2013 Archbishop Jędraszewski notably framed the matter of European identity in racial terms. Criticizing "gender ideology" and blaming it for contributing to the demographic crisis, he said: "I can easily imagine than at some point in the future ... the few white people will be shown to other human races, here, in Europe, just as the Indians are being shown in the US reservations. There lived such people here once, but became extinct on their own wish, because they weren't prepared to accept their biological selves" ("Metropolita łódzki: Przez gender biali mogą być jak Indianie w rezerwatach," Gazeta Wyborcza 17 November 2013, http://wyborcza.pl/1,76842,14966561,Metropolita_lodzki_Przez_gender_biali_moga_byc_jak.html (accessed 26 November 2017))

${ }^{5}$ Giangravè, "Catholic 'Rosary to the Border.",

${ }^{6}$ B. Szydło, Twitter post, 7 October 2017, 8:00, https://twitter.com/BeataSzydlo/status/916679726428762120/ and J. Brudziński, Twitter post, 6 October 2017, 7:10, https://twitter.com/jbrudzinski/status/916304637711527936 (accessed 17 October 2017). 
Holy League defeated the Ottoman fleet, ${ }^{7}$ opens the possibility of additional interpretation of the event's meaning: creating an opportunity for expressing anti-Muslim sentiment, particularly in the context of the refugee crisis in Europe. Bodasiński, asked in an interview for right-wing weekly "Sieci Prawdy" whether any specific events had necessitated such an exceptional national prayer, answered:

Firstly, we are in danger of an armed conflict in Europe. Secondly, there is a threat of Islam: including both terrorist attacks and slow Islamization. Thirdly, perhaps most importantly, Europe is becoming pagan. This means that we are rejecting the protective hand of Providence, which used to shield us. ... With this event we want to say to God: we are asking you for an intervention. $^{8}$

However, shortly after Bodasiński's interview any potentially inflammatory references to Islam seem to have disappeared, and the organizers of the event started representing it as a spiritual rather than political initiative. The head of the Polish Bishops' Conference, Archbishop Stanisław Gądecki, also rejected the interpretation of the event as anti-Islamic and explained that the main goal of this undertaking was "prayer for peace."

"Rosary to the Borders" throws into sharp relief the main concerns of this essay: what are the symbolic means - particularly in the domain of visual displays and performances - that are used in the construction of collective identity in a situation when the rise of right-wing populism puts the definition of "the people" center stage? How is it accomplished within a culture in which large numbers of people seem to believe in the causative power of symbolic - particularly religious - gestures? And what is the role of cultural, particularly religio-cultural, mechanisms in the rise of right-wing populism and how do they interact with political mechanisms? ${ }^{10}$ To answer

7 "The pope at the time, Saint Pius V, called on the whole of Christian Europe to pray the rosary to the Virgin Mary in anticipation of the battle, and after the victory he established the Feast of the Holy Rosary to "Our Lady of Victory."' (Giangravè, "Catholic 'Rosary to the Border"'). Its name was subsequently changed to the Feast of Our Lady of the Rosary.

${ }^{8}$ M. Bodasiński, “Wielkie zaproszenie," interview, Sieci Prawdy 35 (248) 2017, 40.

${ }^{9}$ Abp S. Gądecki, “Abp Gądecki o ‘Różańcu do Granic': Przygotowane nie przez księży, a świeckich. Cel: Modlitwa o pokój," interview, http://www.rmf24.pl/tylko-w-rmf24/rozmowa/news-abpgadecki-o-rozancu-do-granic-przygotowane-nie-przez-ksiez,nId,2449655 (accessed 17 October 2017).

${ }^{10}$ In Poland, as in other complex societies that experience the rise of right-wing populism, there are many different subcultures that may play a role in this process. In this essay, however, we deal solely 
these questions, we first interpret the "Rosary." Then we briefly recollect the way the "first" Solidarity (1980-81) formulated and performed its identity, while challenging the communist monopoly of power. After comparing these two types of performative cultures we introduce our theoretical framework and define the main concepts of this essay: ideological thickening of populism, symbolic thickening of public culture, and discursive opportunity structure. The latter helps us to discuss the relationship between both types of thickening that is then investigated empirically in our analysis of two symbolic transformations: the change in the meaning of the Poznań Monument and the evolution of the meaning of the Polish Independence Day (11 November). We close with some thoughts on the broader political significance of the symbolic and ideological conflict increasingly dominating Polish politics in 2010s.

\section{The Sacralization of Politics and the Politicization of Religion}

One of the key assumptions of classical modernization theory was the idea that modern, complex societies were undergoing inexorable rationalization, secularization and demystification; Entzauberung (disenchantment), as Max Weber called it. While some areas of modern life have certainly undergone such modification, politics have remained symbolically charged, permeated by rituals and symbolic displays that trigger emotions, reinforce a-rational modes of thinking, and confirm conceptions of collective identity. ${ }^{11}$ The cultural and the political are inseparably interwoven, for - on the one hand - "it is simply not possible to insulate [the political realm] from a society's cultural environment"12 as "interpretive coherence for the ambiguities of political life is provided by the symbols, rituals, ceremonies, stories, and drama that permeate politics in a subtle and diffuse way." ${ }^{, 13}$ On the other hand, "politics creates, confirms, or modifies

with the subcultures in which religious elements are prominent and have an elevated role in the construction of collective identities.

${ }^{11}$ M. Aronoff and J. Kubik. Anthropology and Political Science: A Convergent Approach (Oxford: Berghahn Books, 2013), 88-9. Magical thinking has not disappeared in the "advanced" societies of the West. For a recent review of the literature, see E. Subbotsky, "The Belief in Magic in the Age of Science," SAGE Open 4, no. 1 (2014): 1-17.

${ }^{12}$ P. Chabal and J.-P. Daloz, Culture Troubles. Politics and the Interpretation of Meaning (Chicago: The University of Chicago Press, 2006), 61.

${ }^{13}$ J. G. March and J. P. Olsen, Rediscovering Institutions. The Organizational Basis of Politics (New York: The Free Press, 1989), 48. 
interpretations of life. Through politics, individuals develop their identities, their communities, and the public good." 14

Public rituals, an important part of public culture ${ }^{15}$ intricately intertwined with the political domain, are as omnipresent in modern, complex societies as they are in simpler polities. ${ }^{16}$ Their ubiquity is most likely related to the fact that they "reveal values at their deepest level ... men express in ritual what moves them most, and since the form of expression is conventionalized and obligatory, it is the values of the group that are revealed." ${ }^{\prime 17}$ What values are revealed in the "Rosary to the Borders"? The ritual reveals and reinforces people's religiosity and intense patriotism and asserts symbolically that in proposing a vision of "the Polish people" - a quintessentially political act - it is hard to ignore Catholicism as the dominant cultural system of reference. ${ }^{18}$ It also shows that Polish Catholicism, certainly its folk dimension, ${ }^{19}$ is saturated with ritualism, visualism, and magical thinking. ${ }^{20}$

${ }^{14}$ Ibid.

${ }^{15}$ Hariman posits that public culture refers "most broadly to the dynamic negotiation of beliefs, values, and attitudes regarding collective association through media and other social practices that are defined by norms of open access and voluntary response." (R. Hariman, "Public Culture," in Oxford Research Encyclopedia of Communication, online publication date December 2016, http://communication.oxfordre.com/view/10.1093/acrefore/9780190228613.001.0001/acrefore9780190228613-e-32 (accessed 16 December 2017)).

${ }^{16}$ D. I. Kertzer, Ritual, Politics, and Power (New Haven, CT: Yale University Press, 1988); C. Lane, The Rites of Rulers: Ritual in Industrial Society-The Soviet Case (Cambridge: Cambridge University Press, 1981); M. Abélès "Modern Political Ritual: Ethnography of an Inauguration and a Pilgrimage by President Mitterrand," Current Anthropology 29, no. 3 (1988): 391-404.

${ }^{17}$ V. Turner, The Ritual Process. Structure and Anti-Structure (Ithaca, Cornell University Press, 1969), 6. Wilson observes: "I see in the study of rituals the key to an understanding of the essential constitution of human societies" (M. Wilson, "Nyakyusa ritual and symbolism," American Anthropologist 56, no. 2 (1954): 240).

${ }^{18}$ There is a long-standing debate on the link between Catholicism and Polish national identity given that over 90\% of Poles regard themselves as Catholics (see "Przynależność Polaków do ruchów i wspólnot religijnych, Komunikat z badań 84/2017, CBOS, Warszawa, June 2017). We do not doubt that at different levels and in various situations, this link manifests itself in different forms and sometimes may be absent. We want to point out merely that in the 2010s, at the level of "national" discourse this link was intensely promoted, often in elaborate symbolic forms. See also K. Koseła, Polak $i$ Katolik: Splatana tożsamość (Warsaw: IFiS PAN, 2003), B. Porter-Szücs, Faith and Fatherland: Catholicism, Modernity, and Poland (Oxford: Oxford University Press, 2011), M. Grabowska, "Religiosity, the Catholic Church, and Politics in Poland," in Religion, Politics, and Values in Poland, eds. S. Ramet and I. Borowik (New York: Palgrave Macmillan, 2017), 257-88. 
For the participants of Rosary to the Borders, putting on a massive religious ritual seems to have been an efficacious magico-religious method ${ }^{21}$ of dealing with what they perceived as a pressing problem. At the same time, they marked the symbolic boundaries of their "imagined community" and symbolically reinforced their state's political borders (Fig. 2). ${ }^{22}$ Thus, despite its pronounced universalistic intention to bring peace not just to Poland but the whole world, the ritual could be interpreted as an inward looking act of building a "fortress" against real or imagined external enemies. ${ }^{23}$ As such, the ritual was not only a religious act of addressing a deity, but it suggested - rather forcefully - a polarized and religiously inflected division of the world into "us" and "them." Indeed, similar interpretations have emerged and dominated several,

${ }^{19}$ Folk Catholicism, which was the dominant form of religiosity until 1970s, and has since been diffused due to the processes of urbanization and internal migration, to a great extent still shapes some vital traits of common religiosity in Poland. It can be characterized by features such as: collectivism and the importance of the local parish; ritualism and a high degree of observance of collective ceremonies; poor theological consciousness; emotional dimension and familial attachment to the divine persons, saints, and in particular to the Holy Mother; and a belief in miracles and supernatural interventions that engenders admiration of certain miraculous paintings and apparitions, which fuel the powerful pilgrimage culture. See K. Kaczmarek "Polish Religiousness: Mainstream and Peripheries," Religious Studies and Theology 27, no. 1 (2008): 43-68.

20 "Magic fails to acknowledge the distinction between physical and psychological causes, the difference between 'energetic and informational processes.' As Zusne and Jones state it, 'When meaning, instead of the physical processes of energy transfer or information transmission, is taken to be causal, when meaning is externalized or reified, magical thinking enters into this picture."' (R. G. Stayers, Making Magic: Religion, Magic and Science in the Modern World (Oxford: Oxford University Press, 2004), 174).

${ }^{21}$ The Rosary's efficacious potential is attributed to the expected intercession of Virgin Mary. This efficacy is believed to have been revealed in Marian apparitions (e.g. in Fátima). Representatives of the Polish Catholic clergy as well as Rosary's organizers made frequent references to that potential. See for example Polish Bishops' Conference, “Sekretarz Episkopatu: 'Różaniec do granic' - modlitwa za cały kraj i świat,” 7 September 2017, http://episkopat.pl/sekretarz-episkopatu-rozaniec-do-granic-modlitwa-zacaly-kraj-i-swiat/ (accessed 17 October 2017).

${ }^{22}$ On symbolic borders see M. Lamont, S. Pendergrass, M. Pachucki, "Symbolic Boundaries," in International Encyclopedia of the Social and Behavioral Sciences, $2^{\text {nd }}$ Edition, vol. 23, 850-55.

${ }^{23}$ An influential bishop emeritus, Tadeusz Pieronek, said in an interview for Famiglia Cristiana "it is clear that all the Poles who participated in the Rosary are against the thinking and teaching of Pope Francis. Unfortunately. In Poland there is an ongoing battle to persuade people that every refugee is a bandit threatening Polish identity and is a serious and real menace to the health and life of Poles." (Bp T. Pieronek, "La Chiesa Polacca su una strada pericolosa, sostiene il governo e dimentica il Papa," interview, Famiglia Cristiana, 11 October 2017, http://www.famigliacristiana.it/articolo/la-chiesa-polacca-su-unastrada-pericolosa-parla-mons-pieronek.aspx (accessed 17 October 2017)). 
particularly foreign, accounts of this event. " "The people" were constituted relatively narrowly, within the confines of a specifically interpreted ethno-religious idiom. The new religious-political boundary was designed also to protect one's own "cultural substance" against the undesired pollution coming from the outside world, suggesting that we deal here not only with the sacralization of politics, but also with the politicization of religion. ${ }^{25}$

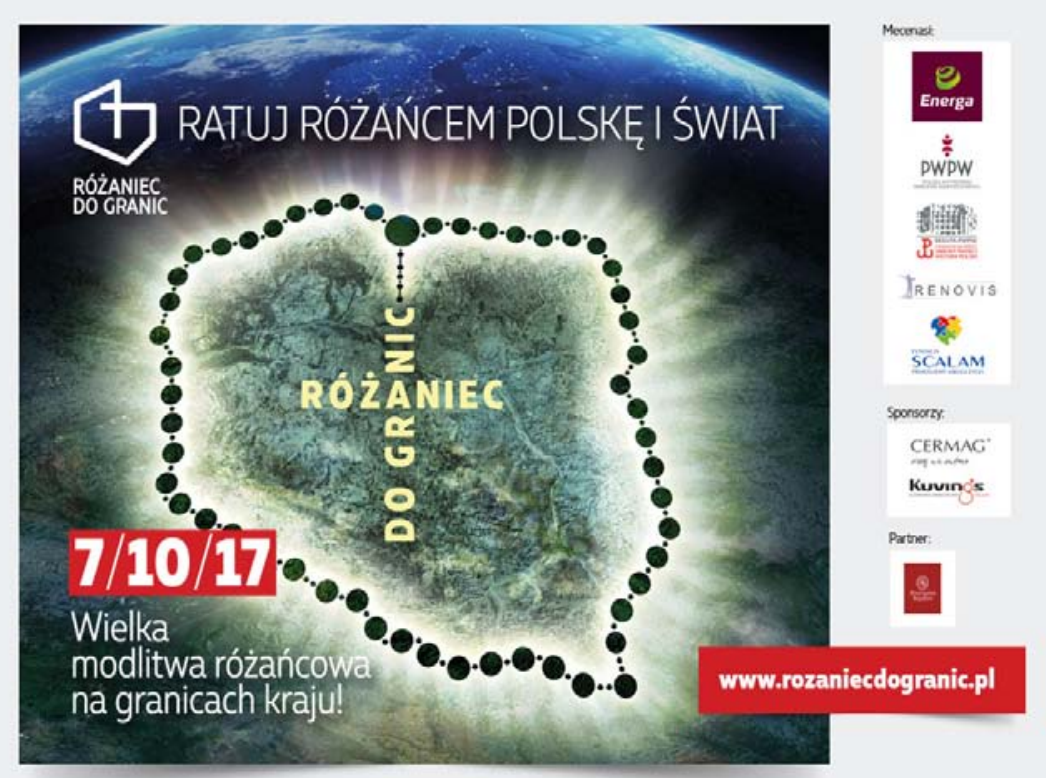

[Fig. 2. Official image publicizing "Rosary to the Borders." Two inscriptions read: "Save Poland and the world with the Rosary" and "7/10/17 A great Rosary prayer at country borders." Copyright http://rozaniecdogranic.pl, promotional materials]

${ }^{24}$ See for instance "1 million Poles prayed against Europe's islamization and for European nations to get back to their Christian roots," Visegrad Post, 11 October 2017, https://visegradpost.com/en/2017/10/11/1-million-poles-prayed-against-europes-islamization-and-foreuropean-nations-to-get-back-to-their-christian-roots/; J. Berendt and M. Specia, "Polish Catholics Gather at Border for Vast Rosary Prayer Event," The New York Times, 7 October 2017, https://www.nytimes.com/2017/10/07/world/europe/poland-rosary-border-prayer.html; "Poland Catholics hold controversial prayer day on borders," BBC, 7 October 2017, http://www.bbc.com/news/worldeurope-41538260 (accessed 17 October 2017).

${ }^{25}$ J. P. Zúquete, "Populism and Religion," in The Oxford Handbook of Populism, eds. C. Rovira Kaltwasser, P. A. Taggart, P. Ochoa Espejo, and P. Ostiguy (Oxford: Oxford University Press, 2017), 445-68. 


\section{Polarizing imagery of Solidarity}

The most powerful rebellion against the communist rule the Soviet Bloc ever experienced, the Solidarity movement, was to a large degree a massive performance of Catholic patriotism imbued with Romantic imagery. The symbolic "tone" of the movement was set during the strikes of August 1980, particularly in Gdańsk. The strike's décor and worker's religious rituals were permeated by Catholic motifs (Fig. 3). The grand themes of Polish Romanticism (for example, the belief in the causal power of words or the sense of extraordinary national mission) were often invoked in the performances of professional artists who joined the workers and in the workers' own poetry. ${ }^{26}$

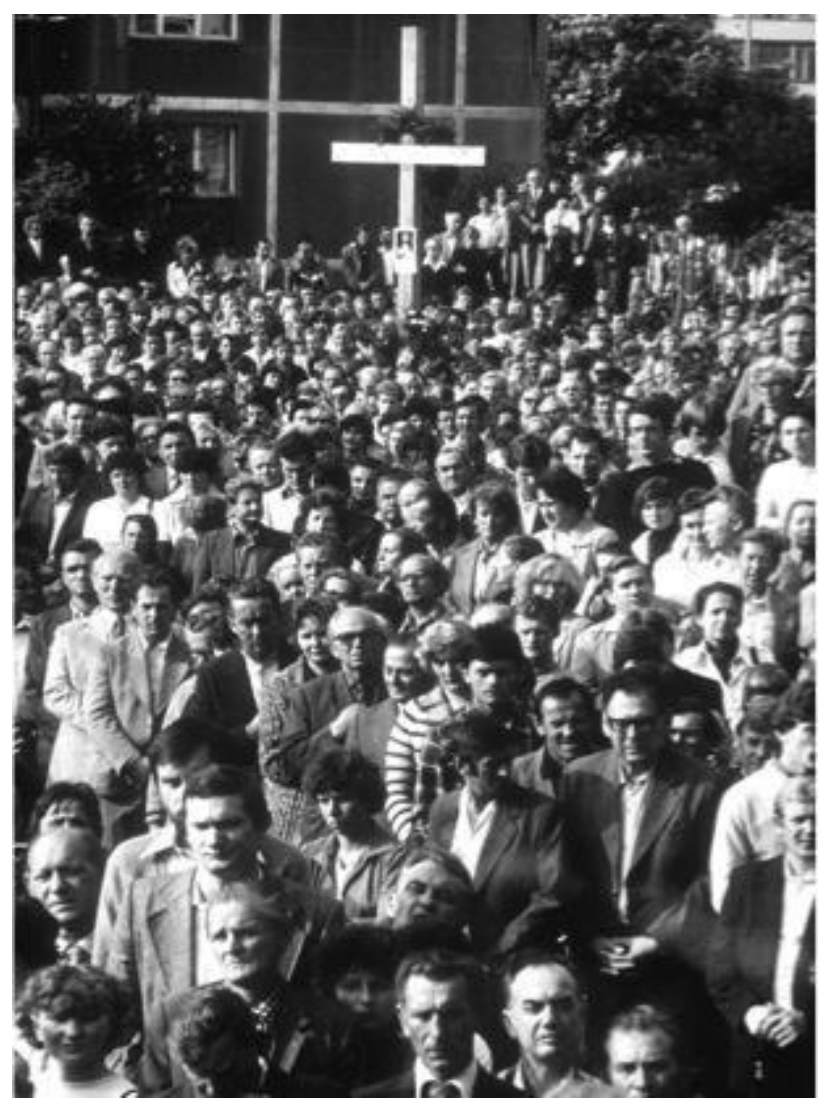

[Fig. 3. Supporters of the striking workers gather at the wooden cross erected outside of Gate Two of the Lenin Shipyard in Gdańsk, August 1980. Copyright Witold Górka]

${ }^{26}$ J. Kubik, The Power of Symbols Against the Symbols of Power. The Rise of Solidarity and the Fall of State Socialism in Poland (University Park: Penn State University Press, 1994), 190-4. 
The Solidarity culture forged in the Gdańsk Shipyard is sometimes interpreted as complex and multi-vocal. ${ }^{27}$ But its basic political imagery was profoundly binary. It projected a picture of the world in which the "good," religious people were sharply juxtaposed to the "bad," secular authorities. It was not a new feature in Polish people's efforts at self-definition, for as Borowik observes: "Before the democratic changes initiated in Poland in 1989, the Church was a key element in the dualistic structure of society - divided into 'bad' communists, belonging to the communist party and its apparatus, and 'good' Polish patriots, belonging to the Roman Catholic Church." ${ }^{28}$ However, prior to 1980, this dualism had never had such a powerful and lavish symbolic elaboration. Between August 1980 and December 1981, this dominant symbolic polarization was reiterated in many performances (including rallies and strikes) and later intensified in the countless "illegal" demonstrations against the communist rulers of the Martial Law regime and its aftermath (1981-89). ${ }^{29}$

How can this polarization be characterized? The idea was to construct sovereign political subjectivity by erecting a symbolic boundary between the "people" and "the rulers," not between "us" and "them" conceived as an alien or undesired social group. ${ }^{30}$ The striking workers and their supporters were delineating a public space within which the Polish people could freely constitute themselves using the available cultural idioms. The version of Polishness people chose to perform on such occasions was "Christian patriotism." With deep roots in Polish history, ${ }^{31}$ it had been earlier deployed by the oppositional movements and the Catholic Church in religious or

${ }^{27}$ P. Rojek, Semiotyka Solidarności. Analiza dyskursów PZPR i NSZZ Solidarność 1981 roku (Kraków: Nomos, 2009).

${ }^{28}$ I. Borowik, "Religion, Politics, and Social Attitudes in Transforming Poland: A Conclusion," in Religion, Politics, and Values in Poland, eds. S. Ramet and I. Borowik (New York: Palgrave Macmillan, 2017), 315.

${ }^{29}$ Martial Law was imposed on Poland by its own government on 13 December 1981 and lasted until 22 July 1982. Its goal was to suppress the Solidarity movement and enhance the communists' grip on power.

${ }^{30}$ This interpretation of Solidarity's dominant message as an inclusive, patriotic yet not nationalistic, and open movement is cultivated by the European Solidarity Center in Gdańsk (as of September 2018).

${ }^{31}$ B. Porter-Szücs “The Birth of the Polak-Katolik," Sprawy Narodowościowe, no. 49 (2017): 2392-2427. 
"illegal" dissident ceremonies of the 1970s to challenge "socialist patriotism," an alternative version of Polishness proposed by the communists. ${ }^{32}$

\section{Thin and Thick Populism. Ideological Thickening of Populism}

In Mudde's ideational approach we adopt, populism is defined as:

a thin-centered ideology that considers society to be ultimately separated into two homogeneous and antagonistic camps, "the pure people" versus "the corrupt elite," and which argues that politics should be an expression of the volonté générale (general will) of the people. ${ }^{33}$

The way the central concept of populism, "the people," is defined is crucial. Populists posit that they hail from the people, understand them, and are their only rightful representatives. But for populists "the people," as Müller aptly puts it, "is a fictional entity outside existing democratic procedures, a homogeneous and morally unified body whose alleged will can be played off against actual election results in democracies." 34 It is, therefore, important to examine the specific constructions of the people that figure in particular populist imaginaries. For, as every skillful political entrepreneur understands, such discursive constructions, to be politically effective, need to reflect, or resonate with, the culture of the people to whom populists appeal. This seems to be one of the reasons, arguably the main one, why populist ideology needs to be "thickened," as its rudimentary, thin version cannot be resonant enough in a specific cultural context.

Additionally, as Mudde argues, "Populism presents a Manichean outlook, in which there are only friends and foes. Opponents are not just people with different priorities and values, they are evil! Consequently, compromise is impossible, as it 'corrupts' the purity." 35 Thin populist

${ }^{32}$ Kubik, The Power, 263.

${ }^{33}$ C. Mudde, "The Populist Zeitgeist," Government and Opposition 39, no. 4 (2004): 543. For a recent review of various conceptions of these three elements see C. Mudde, "Populism: and Ideational Approach," in The Oxford Handbook of Populism, eds. C. Rovira Kaltwasser, P. A. Taggart, P. Ochoa Espejo, and P. Ostiguy (Oxford: Oxford University Press, 2017), 27-47.

${ }^{34}$ J-W. Müller, What Is Populism? (Philadelphia: University of Pennsylvania Press, 2016 Kindle Edition), Kindle locations 396-397.

${ }^{35}$ Mudde, "The Populist Zeitgeist," 544. 
ideology thus tends to be strongly moralistic. ${ }^{36}$ In post-communist contexts right-wing populists often construe their political opponents as morally contemptible "reds" or "pinks" who enjoy power and privileges because of their prior association with, or complicity in, the communist system.

Thin populist ideology "thickens" when it is combined with elements of another ideology or discourse. For example, right-wing populism is an ideological formation fashioned by thickening thin populism with nativism and authoritarianism. ${ }^{37}$ For Mudde, nativism is "an ideology, which holds that states should be inhabited exclusively by members of the native group ('the nation') and that nonnative elements (persons and ideas) are fundamentally threatening to the homogenous nation-state. ${ }^{\prime 38}$ In turn, authoritarianism is defined "as the belief in a strictly ordered society, in which infringements of authority are to be punished severely. In this interpretation, authoritarianism includes law and order and 'punitive conventional moralism."”39 The manner in which both nativism and authoritarianism feature in concrete versions of populist ideology depends on specific socio-cultural contexts that evolve over time.

While we adopt the ideational approach to populism, we enrich it with insights from Moffitt and Tormey's political style approach. In a nutshell, while the former concentrates on the content of populist discourse, the latter urges us to pay equal attention to its form. Moffit and Tormey define political style as "the repertoire of performances that are used to create political relations. ${ }^{, 40}$ In other words, we are asked to observe political theater - the manner in which populists design their visual representations (banners, posters, leaflets, etc.) and stage their public performances (marches, rallies, demonstrations). We are particularly interested in the type of

${ }^{36}$ As Müller writes, "Populism, I suggest, is a particular moralistic imagination of politics, a way of perceiving the political world that sets a morally pure and fully unified — but, I shall argue, ultimately fictional- people against elites who are deemed morally inferior." (Müller, What Is Populism? Kindle locations 288-290).

37 "In the real world most populists combine populism with (features of) one or more other ideologies. So, while populism merely defines the people as pure, the accompanying 'host' ideology can add an additional dimension - such as class in the case of 'social populism' (e.g. March, 2011) and nation in 'national populism' (e.g. Taguieff, 1995).” Mudde, "Populism: and Ideational Approach,” 32.

${ }^{38}$ C. Mudde, Populist Radical Right Parties in Europe (New York: Cambridge University Press, 2007), 19.

${ }^{39}$ Ibid., 23.

${ }^{40}$ B. Moffitt and S. Tormey, "Rethinking Populism: Politics, Mediatisation and Political Style," Political Studies 62, no. 2 (2014): 387. 
political theater that right-wing populists in Poland have created to construct "the people" and to present their values and interests. In the next section we propose a conceptual apparatus that will help us analyze the content of this theater's performances and the cultural and political contexts in which they operate and to which they contribute.

\section{Interaction of Politics and Culture in the Rise of Populism}

Inglehart and Norris contend that "the surge in votes for populist parties can be explained not as a purely economic phenomenon but in large part as a reaction against progressive cultural change. ${ }^{\not 11}$ The Polish case confirms this generalization in a particularly powerful manner. Socioeconomic variables, such as the level of income or the perception of one's household's economic situation are not the best predictors of support for populist parties; socio-cultural variables are. ${ }^{42}$ Many researchers argue that (proto)populist attitudes, driving cultural backlash, lie dormant in some socio-cultural niches of the society, can be activated under specific political conditions and provide support for populist movements and parties. ${ }^{43}$ However, the cultural mechanisms responsible for the emergence and maintenance of such attitudes need to be carefully reconstructed. In other words, while it is hard to deny that culture matters, the existing research on the cultural factors causing the intensifying demand for populist solutions needs to be complemented by the study of the manner in which this demand is met. The significance of the cultural supply side in the explanation of populism's rise is recognized by several scholars who accept the idea that "populism depends on a supply of politicians who articulate the populist message. ${ }^{\circ 4}$ We agree, but will argue that it is not just politicians who formulate and disseminate

${ }^{41}$ R. Inglehart and P. Norris, "Trump, Brexit, and the rise of Populism: Economic have-nots and cultural backlash," HKS Working Paper no. RWP16-026 (2016). See also P. Norris and R. Inglehart, Cultural Backlash. Trump, Brexit, and the Rise of Authoritarian Populism (New York: Cambridge University Press, 2018).

${ }^{42}$ R. Markowski, “Creating Authoritarian Clientelism: Poland After 2015,” Hague Journal on the Rule of Law (published online 24 September 2018).

${ }^{43}$ K. Hawkins, M. Read and T. Pauwels, "Populism and Its Causes," in The Oxford Handbook of Populism, eds. C. Rovira Kaltwasser, P. A. Taggart, P. Ochoa Espejo, and P. Ostiguy (Oxford: Oxford University Press, 2017), 275-6.

${ }^{44}$ Ibid., 277. See also L. Rensmann. "The Noisy Counter-Revolution: Understanding the Cultural Conditions and Dynamics of Populist Politics in Europe in the Digital Age," Politics and Governance, 5, 4 
populist narratives and are thus responsible for the intensification of populist sentiments; actions of various cultural entrepreneurs seem to be equally if not more consequential. In our work that contributes to the study of the populist discursive field in Central and Eastern Europe and particularly Poland, ${ }^{45}$ we utilize the insights of critical discourse analysis, especially its branch that focuses not only on texts but also on visual rhetoric. ${ }^{46}$

By studying actions of cultural entrepreneurs who deliberately engineer public culture, usually acting outside of "formal" politics but often in concertation with politicians, we reconstruct a cultural mechanism that is responsible for creating what Rensmann calls the "cultural conditions favorable for authoritarian populist mobilizations." ${ }^{47}$ We show how this mechanism contributes to the formation and/or "reproduction of stable, resilient authoritarian legacies and cultural undercurrents within liberal democracies. ${ }^{48}$ We do not argue that cultural mechanisms are solely responsible for the rise of populism and should substitute political and economic mechanisms in scholarly analyses. Together with several other authors, we assume that the rising political influence of populism is the result of what Myrdal called a circular cumulative causation in which economic, political and cultural factors interact with each other. ${ }^{49} \mathrm{We}$ elucidate a specific supply side cultural mechanism (symbolic thickening of public culture) and offer a theoretical account of how it interacts with a political mechanism of ideological

(2017): 123-135, and S. Bornschier, "The New Cultural Divide and the Two-Dimensional Political Space in Western Europe," West European Politics, 33, 3 (2010): 419-444.

${ }^{45}$ D. Płatek and P. Płócienniczak, "Mobilizing on the Extreme Right in Poland. Marginalization, institutionalization, and radicalization," in Civil Society Revisited. Lessons from Poland, eds. K. Jacobsson and E. Korolczuk (New York: Berghahn, 2017), 287-313; B. Pytlas, Radical Right Parties in Central and Eastern Europe: Mainstream Party Competition and Electoral Fortune (London: Routledge, 2016); B. Pytlas and O. Kossack. "Lighting the Fuse: the Impact of Radical Right Parties on Party Competition in Central and Eastern Europe," in Transforming the Transformation? The East European Radical Right in the Political Process, ed. M. Minkenberg (London: Routledge, 2015), 105-136; J. Kajta, "Discursive Strategies of Polish Nationalists in the Construction of the Other. The Case of Muslims and Homosexuals," Intersections. EEJSP 3, 3 (2017): 88-107.

${ }^{46}$ See, for example, R. Wodak and B. Forchtner, "Embattled Vienna 1683/2010: right-wing populism, collective memory and fictionalisation of politics," Visual Communication 13, 2 (2014): 23155.

${ }^{47}$ Rensmann, "Noisy Counter-Revolution," 129.

${ }^{48}$ Ibid., 127.

${ }^{49}$ G. Myrdal, "Principle of Circular and Cumulative Causation," in Economic Theory and Underdeveloped Regions (London: Methuen and Co., Ltd., 1957), 11-22. We do not attempt a full reconstruction of a causal "circle" involving economic, political, and cultural factors and concentrate on a single cultural mechanism construed as a fragment of such a circle. 
thickening of populism to intensify a specific understanding of Polishness and enhance the popularity and influence of right-wing populism. In this task we are aided by the concept of discursive opportunity structure.

In an essay on what she calls Polish national sensorium, Zubrzycki argues that “...national mythologies are compelling insofar as the myths that comprise them are complementary, reinforcing, or overlapping at a given time." ${ }^{\text {50 }}$ There are, however, distinguishable levels or intensities of complementarity, reinforcing and overlapping in myths or symbolic systems. Let us examine three situations in order to develop the concept of symbolic thickening of public culture and its role in the construction of the image of national community.

Such a community can be signified by a single symbol that will tend to have a narrow intension (few attributes) ${ }^{51}$ and thus broad extension (it is applicable to many referents). As such it can appeal to or attract a relatively large and varied set of people, as it potentially denotes many conceptions of a given community. For example, a national flag suggests "nation-ness" as a single, relatively uncomplicated attribute and therefore references many different "nations" understood as differently imagined communities. Both a moderate patriot and a chauvinist "see" their respective "nations" in such an austere and thus (potentially) multi-vocal, polysemic or multi-referential symbol. ${ }^{52}$ In other words, the flag, standing alone, is to a large degree a floating signifier, ${ }^{53}$ as it may be "filled with content" in many different, even contradictory, ways.

When it comes to symbolic performances, however, it is rarely the case that they display a single symbol; they usually employ a few symbols that can be interpreted as a system. The semantic relation or cross-referencing (Zubrzycki's complementarity, reinforcing and overlapping) between its elements may range from tight and intense to virtually non-existent. The

${ }^{50}$ G. Zubrzycki, "History and the National Sensorium: Making Sense of Polish Mythology," Qualitative Sociology 34 (2011): 21-57.

${ }^{51}$ Intension (connotation) of the sign or symbol is defined here as a set of attributes ascribed to the objects that are referents of this sign. The set of the referents is the sign's extension (denotation).

${ }^{52}$ Influenced by Turner, we see national flags, particularly when displayed during ritual performances as both referential and condensation symbols. The formers' dominant function is to communicate cognitive content, while the latter arouse or release both conscious and unconscious emotions. A national flag is a dominant symbol in a symbolic system designed to signify "the nation." As such they are multivocal and polysemic. See, for example, Turner, The Ritual Process.

${ }^{53}$ A floating (or empty) signifier does not have a single, clear signified element associated with it. It can easily be associated with various referents or ideas, often as a result of struggles for cultural/discursive hegemony. 
degree of tightness/intensity of this relation can be identified by reconstructing the way in which the symbols are assembled within a system. If it is constructed by its creators and subsequently construed by the audience as rather loosely assembled, in a mechanism that resembles the logical operation OR, each symbol can be seen as relatively separate and therefore attract or resonate with a different discursive community. Thus the symbolic system based on this logic - let's call it "thin" - can be seen as "our own" by several, culturally dissimilar, groups of people. ${ }^{54}$

If, however, the mechanism by which the symbols are connected appears to be of the AND type, it is difficult to interpret each symbol separately. Rather, they appear to constitute a single whole and thus appeal mostly, if not exclusively, to a discursive community that is "ready" to embrace the wholesale vision that it represents. Here we deal with a "thick" symbolic system that contains several symbols tightly cross-referenced via an AND-mechanism. Such a system's intension is rich, expansive (it has several mutually reinforcing attributes) and thus, per force, its extension is narrow (it has a smaller set of referenced "objects"). For example, "nation-ness" imagined in a symbolically thick manner, with several connected attributes, references a highly specific understanding of the "nation." In other words, such a symbolic system tends to become mono-vocal, since its referent is narrower, as in a singular version of nation-ness that is recognizable or appealing usually to a relatively small set of people. As a consequence, the people who are left out reimagine themselves by means of different symbolic systems, for example alternatively construed "nations." As a result, thick symbolic systems enhance cultural, thus also social, fragmentation or polarization. ${ }^{55}$

"Thick" symbolic systems tend to attract fewer people than "thin" ones. There are, however, situations when larger numbers of people accept, in a manner that is either genuine or simulated, having their collective identity defined in terms of a thick symbolic system, signifying a "narrow" conception of the nation. This is particularly pronounced during revolutionary upheavals or in authoritarian (and particularly totalitarian) countries, such as Nazi Germany or

\footnotetext{
${ }^{54}$ To use terms borrowed from Laclau, in this situation a broad, inclusive form of collective identity can be hinted at, as what he calls the differential mode of constituting identity (that locks people in narrow sub-cultures) may be complemented but not overridden by the equivalential mode that emphasizes commonality. The constitutive units retain many if not most of their different attributes (in the minds of the participants) and this difference is seen as more central, important than the commonality that is merely hinted at. See E. Laclau, On Populist Reason (London: Verso, 2005).

${ }^{55}$ To use the Laclaulian language again, in a discursive community constituted by a thick symbolic system the sense of equivalence is far more dominant than the sense of difference.
} 
Stalin's Soviet Union, that institute tight censorship, practice intimidation, and as a result eliminate or limit the possibility of articulating and displaying publicly competing visions of the nation.

The symbolic system of Solidarity, a powerful tool of polarization, ${ }^{56}$ contained several symbols that - we contend - referenced each other rather loosely; it was a thin symbolic system. Crucially, the famous Solidarity logo, by far the most dominant visual emblem of the movement, represented and reinforced the very idea of solidarity uniting people of different backgrounds and political convictions. ${ }^{57}$ Similarly, the Christian Cross, often used in the movement's ceremonies, did not seem to have been interpreted by the audience as a single, exclusionary symbol of PolishCatholic identity. "Liberal" Catholics, "national" Catholics, devout believers and secular champions of national independence could "see" their imagined communities embraced in a broadly conceived image of the "people," represented by several, loosely connected, symbols, dominated by the Solidarity logo. ${ }^{58}$ Moreover, the key symbols of the movement were not referencing "people" as defined in contradistinction to other "people," but to "the authorities." In essence, while the discourse of Solidarity was polarizing, most of the time it refrained from defining the "other" in ethnic or religious terms; the enemy was "the communists" and their system.

The symbolism of "The Rosary to the Borders" was "thicker," as the Rosary as a marker of magico-religious power simultaneously became a visual device that outlined the state borders and marked an exclusionary conception of national identity; the image suggested that they were inseparably intertwined. The essence of the associated performance was a prayer that is believed to have causal power to change reality; it is not merely an act of signifying collective identity. The praying "Polish people" (not simply Catholics) are the collective agency endowed with that

${ }^{56}$ Kubik, The Power, 266.

57 "Solidarity became such a formidable opponent of communism because it managed to mobilize millions of people through producing strong emotional attachment to a set of 'a-political' symbols and discourses. They were a-political in the sense that they stood for neither 'left' nor 'right;' neither centralization nor decentralization; neither authoritarian leadership nor participatory democracy. But they allowed the huge masses of people to win back their self-respect and dignity." (J. Kubik, "Who Done It? Workers or Intellectuals. A Controversy over Solidarity's Origins and Social Composition," Theory and Society 23 (1994): 460).

${ }^{58}$ The "Solidarity" logo was the dominant summarizing symbol of the movement. It is also an example of a symbol that is simultaneously discursive and presentational. For a brief discussion of these concepts see Aronoff and Kubik, Anthropology, 70. 
power. Moreover, the performance suggested to its audience a much more specific understanding of the relationship between Catholicism and national identity. Its dominant symbol, the borders of Poland delineated with the Rosary, set Poles apart from other nations and religious others, not from "the authorities," as was the case with the symbolism of Solidarity.

The difference between thin and thick symbolic systems has political consequences. While the former are associated with a more inclusive, open visions of collective identity, the latter serve to define narrower visions. A transformation of a thin system of symbols pertaining to a specific referent (for example, the "nation") into a thick one - that we call symbolic thickening - portends therefore a momentous political change. Inspired by Mudde's distinction between thin and thick populism, in the rest of the essay we investigate the interaction between symbolic thickening of public culture and the ideological thickening of populism and argue that it is neither direct, nor unidirectional - contrary to the analysts of the supply side of populism and its influence on the symbolic sphere. Populist ideologies do have an impact on public culture, as they claim, but it is also the case that symbolic thickening creates conditions conducive to the ideological thickening of populism, particularly when it happens simultaneously at several levels of cultural production. To capture the nature of this process we employ the concept of discursive opportunity structure.

Koopmans and Stratham introduced the concept of discursive opportunity structure to the literature on social movements and protest politics in 1999, as a conceptual expansion of the concept of political opportunity structure. Guided by this concept researchers are supposed to study

political-cultural or symbolic external constraints and facilitators of social movement mobilization. We propose to denote this set of variables by the term discursive opportunity structure, which may be seen as determining which ideas are considered "sensible," which constructions of reality are seen as "realistic," and which claims are held as "legitimate" within a certain polity at a specific time. ${ }^{59}$

We look for such "constructions of reality" among the visual symbols and symbolic performances that thicken public culture and thus create discursive opportunities for populist

${ }^{59}$ R. Koopmans and P. Statham, "Ethnic and Civic Conceptions of Nationhood and the Differential Success of the Extreme Right in Germany and Italy," in How Social Movements Matter, eds. M. Giugni, D. McAdam, and C. Tilly (Minneapolis, MN: University of Minnesota Press, 1999), 228. 
actors, particularly those whose ideology already includes religious elements. ${ }^{60}$ In the Polish context - as we argued above - not only nativism and authoritarianism, but also Roman Catholicism, often in its exclusionary, "nationalized," "folksy" ethno-religious version is a frequent, if not the dominant, "thickening agent." We analyze two cases. The first is the 2006 change of the inscription on the Poznan Monument commemorating the 1956 revolt and the people killed by the communist security forces. The second is the evolution of the Polish Independence Day celebrations. We argue that both changes result in a significant transformation of meaning that we interpret as symbolic thickening of national identity. This is accomplished by cultural entrepreneurs who combine symbols taken from the historically shaped reservoir of both national and religious motifs and help to create - even if inadvertently - conditions conducive to the ideological thickening of populism.

\section{Poznań June 1956 Monument}

In June 1956, around 100,000 people took to the streets of Poznań in the first major protest against the communist rule in Poland. ${ }^{61}$ The protest began as a spontaneous strike in the massive Joseph Stalin Metal Works, broadly known as "Cegielski." The workers walked out, others joined them along the way, and the protest culminated in a huge rally at Adam Mickiewicz Square. During the violent clashes with the police and the army, 57 people were killed and

\footnotetext{
${ }^{60}$ Not all populists benefit from this phenomenon - some actors due to their ideological
} heterogeneity (Kukiz'15) or ambiguity (Self-defense) may owe their popularity and electoral support to their novelty and/or ability to appeal to voters disenchanted with mainstream parties. In this article we focus only on the discursive opportunity structure created for those populist movements whose ideologies are "thickened" with religious themes and who interact with symbolically thickened ethno-religious subcultures. On the complex ideologies of other populist movements see for example B. Stanley, "Defenders of the Cross: Populist Politics and Religion in Post-Communist Poland," in Saving the People: How Populists Hijack Religion, eds. D. McDonnell, N. Marzouki, and O. Roy (Oxford: Oxford University Press, 2016), 109-128 and B. Stanley and M. Cześnik, "Populism in Poland," in Populism Around the World. A Comparative Perspective, ed. D. Stockemer (Cham: Springer, 2019), 67-87.

${ }^{61}$ The significance of the June 1956 events in Poznań is hard to be overestimated - it was not only the first mass strike against the communist rule but, as Machcewicz argues, also the only such event in which civilians were engaged in regular combat with the use of weapons against the armed forces; it can thus be considered as the last act of violent insurgence in modern Poland. See P. Machcewicz, Rebellious Satellite. Poland 1956 (Stanford: Stanford University Press, 2009). 
hundreds injured. ${ }^{62}$ The communist authorities did not allow commemorating this tragedy, so for years its memory was preserved only in the private lore of many communities and families. This changed in 1981, during the thirteen-month period of first Solidarity's legal existence, ${ }^{63}$ when the union activists formed a committee that commissioned a monument ${ }^{64}$ and organized the unveiling ceremony. The goal was to commemorate the rebellion and particularly the fallen. The celebrations took three days, 27-29 June 1981, and - as in almost all Solidarity ceremonial events - they included a Catholic Mass.

The monument unveiled on 28 June was composed of three elements: two crosses, twenty-one and nineteen meters high, and a stylized head of an eagle emerging from what looks like a base of the third incipient pillar or cross. The simple construction of the crosses and their heavy, slightly rough look evoke associations with heavy industry - the two pillars become crosses thanks to a horizontal bar tied to them with a thick rope. The cross on the left bears the date of the Poznań revolt, 1956, while the dates of other revolts against the communist power, 1968, 1970, 1976, 1980, and 1981 are emblazoned on the right cross. ${ }^{65}$ The slogan which had

${ }^{62}$ Ł. Jastrząb, “Wokół obchodów rocznic Poznańskiego Czerwca 1956 r. W latach 1990-2016,” unpublished manuscript, n.d., 14.

${ }^{63}$ The Independent Self-governing Labor Union "Solidarity” was registered on 17 September 1980 as a result of the Gdańsk Agreement and delegalized on 13 December 1981 upon the introduction of Martial Law by the Military Council of National Salvation. It was by far the most consequential independent organization of civil society ever created in any communist country. See, J. Kubik, "Solidarity," in International Encyclopedia of Revolution and Protest 1500-Present, ed. I. Ness (Oxford: Blackwell Publishing, 2009), 3072-80.

${ }^{64}$ For a description of the competition for the monument's design see P. Cieliczko, "Pomnik ofiar czerwca 1956 (Poznańskie Krzyże)," 8 August 2016, https://www.miastopoznaj.pl/blogi/z-poznania/4158pomnik-ofiar-czerwca-1956-poznanskie-krzyze (accessed 20 December 2017). Other proposed designs can be seen on the Institute of National Remembrance website, http:/czerwiec56.ipn.gov.pl/c56/walka-opamiec/konkurs-na-pomnik-foto/9212,Konkurs-na-pomnik.html (accessed 20 December 2017). A brief description of the unveiling ceremony in English can be found on the website by the Poznan City Council "Poznań June 1956 Uprising," n.d., http://www.poznan.pl/mim/czerwiec56/en/themonument,p,3043,3744,3746.html (accessed 20 December 2017).

${ }^{65}$ The last date, 1981, was added in 1991, during renovation. See Cieliczko, "Pomnik ofiar." 
come to symbolize ${ }^{66}$ the 1956 rebellion, "For Freedom, Law and Bread" is engraved on the eagle's torso (Fig. 4). ${ }^{67}$

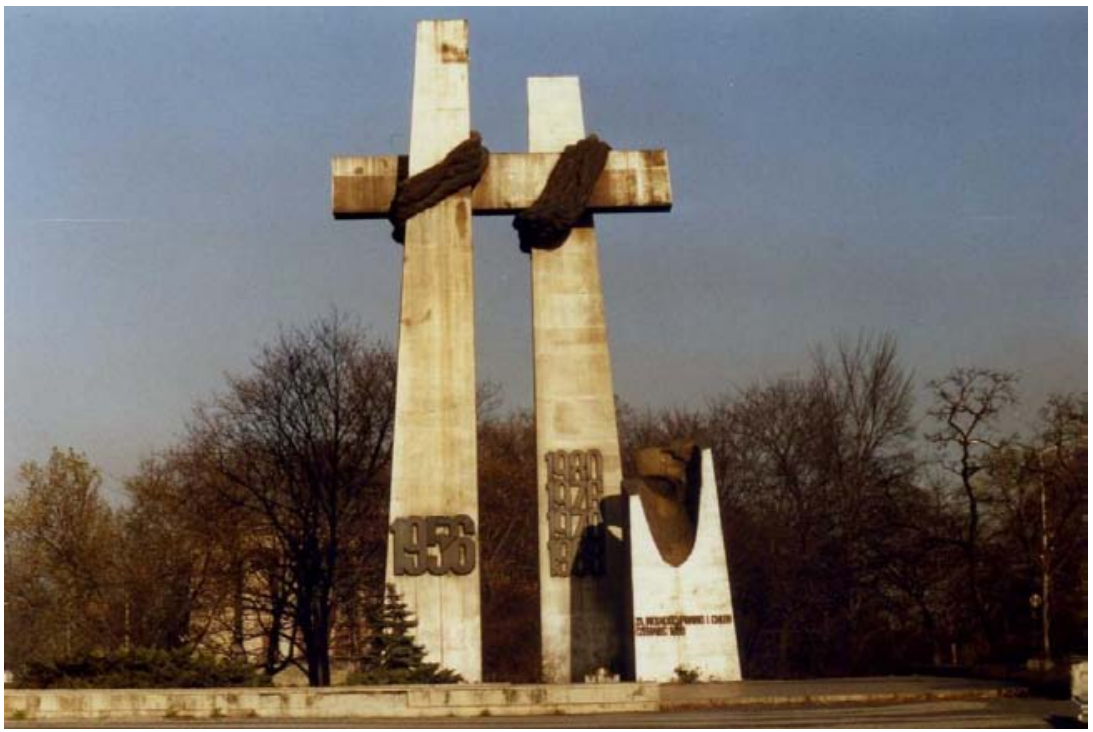

[Fig. 4. The Poznań monument as unveiled on 28 June 1981. Copyright Sludge G, flickr.com. CC BY-SA 2.0]

The monument's meaning has never been purely secular. Its dominant element, the crosses, leaves little doubt that the meaning of the whole is associated with Christianity, and the Catholic funerary rite in particular. The intentions of the creators are clearly recorded on the cornerstone of the monument, whose long inscription ends with the following words: "Laying down this Cornerstone for the Eternal Memorial, we trust that Christ, Who endowed the cross with Redemptive Dignity, will become a source of Dignity and strength for those who will stop in front of this monument." ${ }^{68}$ Additionally, the composition, in which the eagle's head is set aside the crosses, the White Eagle being the Polish national emblem, symbolizes strong connections between Polishness and Catholicism.

66 "In popular thinking, the Poznań June is symbolised by two placards, 'Bread' and 'Freedom,' which the demonstrators placed on the headquarters PUWP Provincial Committee," (Machcewicz, Rebellious satellite, 102).

67 "After a number of discussions, on 6 February 1981, a design of Adam Graczyk, sculpturer (sic) and Włodzimierz Wojciechowski, architect, with a 'Unity' sign was selected for execution. Two marching crosses with one joint arm, with chains on it, and on their side an eagle watching them." See "Poznań June 1956 Uprising."

\footnotetext{
${ }^{68}$ Kubik, The Power, 214-15.
} 
During the Martial Law period, the square in front of the monument was the location of several anti-regime demonstrations. In 1983, Pope John Paul II was not allowed to conduct a Mass there, but while in Poznań he talked about the monument's meaning, reminding his listeners of the prior religious significance of its location. ${ }^{69} \mathrm{He}$ conducted the Mass at the monument for the first time on 3 June 1997. Such symbolic performances, particularly the papal visit, were vehicles for adding new layers of meaning to the monument, yet none of them - by their very nature fleeting and most likely remembered only by the participants - could have a durable transformative effect that adding a new phrase to the inscription had. This happened in 2006 , shortly before the celebrations of the $50^{\text {th }}$ anniversary of the revolt, when the words "For God" were inscribed above the earlier text, unequivocally associating the meaning of the monument, and thus the tragic events, with religion (Fig. 5). ${ }^{70}$

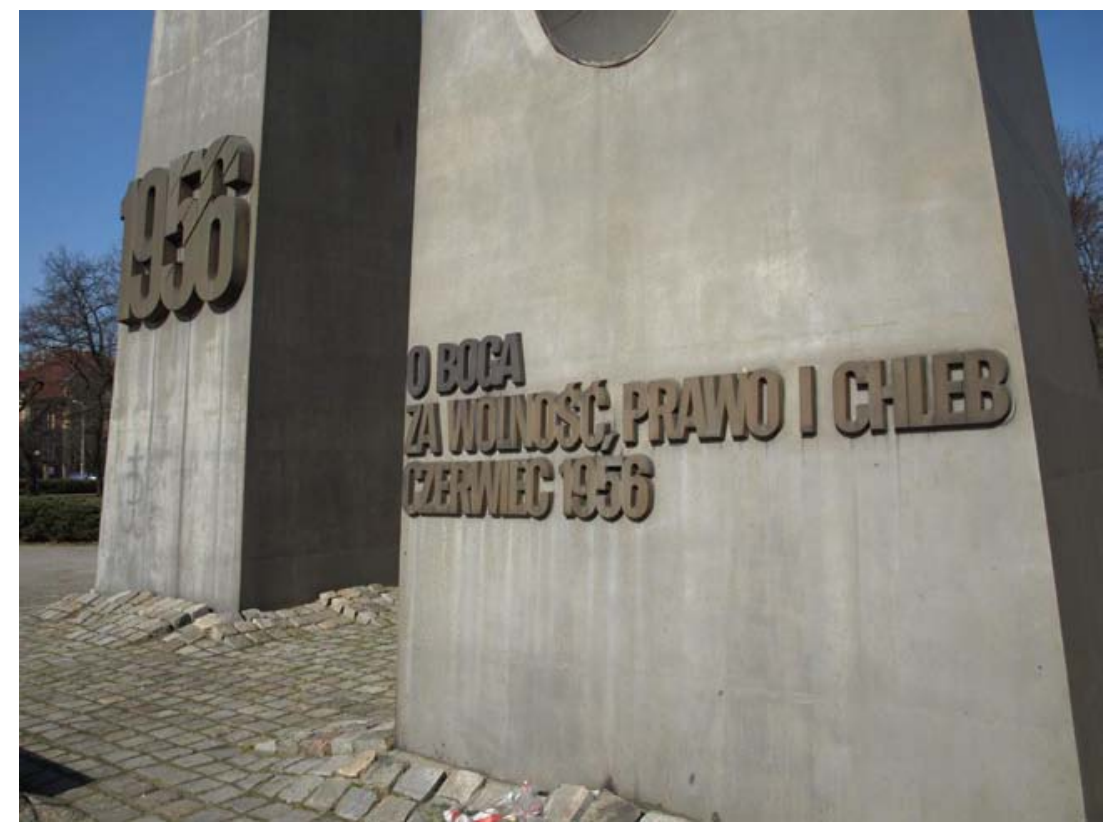

${ }^{69}$ John Paul II during a meeting with Poles on 12 October 1986 elaborated on the Catholic valence of the Poznan monument: "It is telling that the Poznan's double Cross, which commemorates the June tragedy, is also evidence of the power with which the human spirit, the Polish spirit, constantly desires to draw from the Cross of Christ. This Cross, it is worth recalling, stands in the place of the monument of the Sacred Heart of Jesus, erected in Poznań as a votive offering for the independence regained in 1918, which during the occupation was destroyed by the Germans." (Cieliczko, "Pomnik ofiar").

${ }^{70}$ During the 2006 refurbishment, a plaque commemorating the papal mass from 1997 was added to the site (the square). While not a direct intervention into the materiality of the monument, this act strengthens the religious denotation of the monument. 
[Fig. 5. "For God" added to the inscription on the Poznań monument in June 2006. Copyright R-Frank / Poznań Wikia, public domain]

This act of reinscription of the monument's intended message has triggered a controversy, at least among some historians and journalists who have claimed that during the actual revolt "the slogans related to religious freedom did not appear, and the Church's representatives did not engage in this workers' rebellion." ${ }^{71}$ While the initial demands were predominantly economic as most historians seem to agree - and included "bread, lower prices, lower norms of work, and higher wages," political demands were quickly added. Szczesiak-Ślusarek reviews the protest slogans and concludes: "The importance of the motif of a demand for freedom increased with every hour of the protests. The protesters wrote on an overturned tram: 'away with the dictatorship!' They called: 'away with the communists!' 'away with such freedom!',,72 Not unexpectedly, such calls, appearing in an "elevated atmosphere [that] was augmented with political and religious songs,",73 were intertwined with demands for religious freedom, as antiofficial patriotism in the communist People's Republic almost by default was associated with Catholicism. "We want a Catholic, not Bolshevik Poland",75 and "we want religion back in schools," some people demanded. ${ }^{76}$

Regardless of the actual significance of religious motifs in the 1956 protests and following a long series of performative (re)interpretations (for example via the papal intervention), the act of reinscription makes it difficult, if not impossible, to see the 1956 protestors as merely workers demanding their economic rights or patriots pressing for more sovereignty from the Soviet Union. They were primarily, or at least simultaneously, Catholics demanding freedom for expressing their religious convictions.

${ }^{71}$ Cieliczko, "Pomnik ofiar."

${ }^{72}$ M. Szczesiak-Ślusarek, “Away with such Freedom,” in Poznań 1956 Protests (Warsaw, Pamięć.pl Monthly, n.d), 10.

${ }^{73}$ Ibid., 10.

${ }^{74}$ See Kubik, The Power.

${ }^{75}$ Muzeum Historii Polski, "Poznański Czerwiec,” 23 June 2017, http://muzhp.pl/pl/c/1701/poznanski-czerwiec (accessed 18 November 2017). See also Machcewicz, Rebellious satellite, 102.

${ }^{76}$ Szczesiak-Ślusarek, “Away with such Freedom," 10. On Christian patriotism see Kubik, The Power, 121-25 and D. Szeligowska, Polish Patriotism after 1989. Concepts, Debates, Identities (Oxford: Peter Lang, 2016), 48. 
The effect of adding a new symbolic element, a two-word phrase (For God), is the change of overall meaning of the monument and its symbolic thickening. The new inscription signals unequivocally that the people who were demanding "Freedom, Law and Bread" need to be construed also as Christians and that in the Polish context by cultural default means Catholics. The protestors' demands, therefore, cannot be seen as exclusively economic and political but also as religious (thus cultural), as - it is now emphasized - the revolt's participants demanded the recognition of their Catholic identity. Importantly, the fallen can now be seen also as martyrs sacrificing their lives for the faith. Moreover, this semantic shift was not accomplished by a mere administrative fiat, but by the means of a religious ritual: a procession organized as the Way of the Cross, led by Bishop Marek Jędraszewski, then of Poznań. ${ }^{77}$ Polish public culture that frames political contests acquired one more signifier indicating that for many, the terms of this contest are religious.

\section{Polish Independence Day: 11 November}

In November 1918, after 123 years of political non-existence and the devastating World War I, Poland regained independence. Among several conflicts shaping the political life of the new republic, the polarizing antagonism between the supporters of Józef Piłsudski on the one hand, and Roman Dmowski on the other, was dominant. ${ }^{78}$ Piłsudski embodied the Romantic

${ }^{77}$ According to the official website launched for the $50^{\text {th }}$ anniversary of the events, the changes in the monument's inscription were motivated by the necessity to give justice to the workers religious demands: "The monument in Mickiewicz Square and its surroundings were renovated. Because the documents of the Institute of National Remembrance show that the demonstrating Poznan residents were singing 'God save Poland,' carried placards with slogans such as 'We want God,' and demanded the return of religion to schools, the phrase 'For God' has been added to the monument's existing inscription 'For freedom, law and bread.' In 1981, when the monument was unveiled, it was not possible to place an appeal to God yet." (“Inauguracja obchodów czerwca - wydarzenia przed 28 czerwca 2006 r.," n.d., http://www.poznan.pl/mim/czerwiec56/inauguracja-obchodow-czerwca-wydarzenia-przed-28-czerwca2006r,p,3043,6076,6080.html (accessed 18 November 2017)). In 2011 a group of anarchists proposed the further reinterpretation of the monument's meaning by changing the phrase "O Boga" into "O Bogatych" (in translation, "For God" into "For the rich"). See, Ł. Jastrząb, "Wokół obchodów," 5.

${ }^{78}$ Joseph Rothschild summarized the situation pithily: "Interwar Poland's foreign and domestic stances were to a large extent determined by the historic vision of Józef Piłsudski - and by the Right's deliberate frustration of that vision." (J. Rothschild, East Central Europe between the Two World Wars (Seattle and London: University of Washington Press, 1974), 33). 
tradition of fighting the oppressor by all available means, never collaborating, and unequivocally supporting the multi-ethnic and multicultural vision of "political" patriotism. Dmowski, by contrast, is associated with the idea of ethnically homogenous nation, with strong anti-Semitic overtones. Springing largely from those two radically different visions of the nation, ${ }^{79}$ the tension was tearing apart also the domain of national ceremonial and collective memory, as for a long time competing political camps could not agree on a common date to celebrate the regaining of independence.

Only on 23 April 1937, two years after Piłsudski’s death, the Parliament passed a bill establishing the national holiday that was celebrated for the first time on 11 November that year. ${ }^{80}$ This date was associated with the Piłsudskiite camp, as a day after his return to Warsaw (10 November 1918) Piłsudski was given the authority over the Polish army and was accepted the de facto leader of the nation. The holiday became a primary performative vehicle for the political mythology that has his cult at its center. ${ }^{81}$

During the Nazi occupation (1939-1945), the holiday was abolished. After 1945, the ruling communists attempted to ascribe Poland's regaining its independence in 1918 to the Russian Revolution, while they also instituted a new National Day of Poland's Rebirth on 22

${ }^{79}$ Brykczynski captures the most popular view of Piłsudski, when he notes: "The Marshal is most often portrayed as a traditional or even anachronistic patriot, who represents what was best in the multicultural traditions of the early modern Polish-Lithuanian Commonwealth, as these are encapsulated in the famous adage gente Ruthenus natione Polonus (of the Ruthenian people but of Polish nationality)" (P. Brykczynski, "Reconsidering "Piłsudskiite nationalism," Nationalities Papers, 42 (2014): 772).

Dmowski's ideas are sometimes presented as "realist," as he and his followers "fiercely opposed the more open and tolerant civic tradition of earlier generations, which they saw as outdated, utopian, and romantic" (ibid.). For the summary of the debate on the "realist" version of Polish patriotism and Dmowski's role in its formulation and dissemination, see Szeligowska, Polish Patriotism, particularly pages 40-44.

${ }^{80}$ Historia Zapomniana, "Historia Święta Niepodległości,” 11 November 2015, https://historiamniejznanaizapomniana.wordpress.com/2015/11/11/historia-swieta-niepodleglosci/ (accessed 18 November 2017). Article 1 of this bill, published in the Monitor under the number 33, states: "The Day of November 11, as an anniversary of regaining by the Polish Nation of sovereign state existence and as a day forever associated with the great name of Józef Pilsudski, the victorious Leader of the Nation in the struggle for Motherland's freedom is the celebratory Independence Day" TRANS. See "11 listopada 1937. Pierwsze obchody Święta Niepodległości jako święta państwowego," 11 November 2013, http://nowahistoria.interia.pl/kartka-z-kalendarza/news-11-listopada-1937-pierwsze-obchodyswieta-niepodleglosci-jak,nId,1056278 (accessed 19 November 2017).

${ }^{81}$ For an elaborate argument in support of this interpretation see M. B. B. Biskupski, Independence Day: Myth, Symbol, and the Creation of Modern Poland (Oxford: Oxford University Press, 2012). 
July, to commemorate the creation of a Soviet-imposed communist Polish government in 1944. But although the celebrations of 11 November were officially banned, some oppositional circles still gathered on that day and with time even the communist authorities started reviving some elements of the holiday, mostly related to the Piłsudski cult. ${ }^{82}$ In the 1970 s, the Party kept associating the meaning of 11 November with a mythology built around the paradigm of "socialist patriotism" and "progressive" historical turn initiated by the Bolshevik Revolution. ${ }^{83}$ By the end of the 1970s, dissidents representing several political camps were challenging the communist monopoly of power, not only by means of bottom-up mobilization and underground publishing but also by breaking the communist hold on public space. The anniversary of 1918 became a regular feature in the unofficial ceremonial calendar in the form of Catholic Masses, illegal marches, and rallies. ${ }^{84}$ The path breaking and - given the communist ban - spectacular celebrations organized by several dissident groups in 1978 are a case in point. ${ }^{85}$ The main organizers came from the "right" side of the dissident milieu, the most prominent being ROPCiO (the Movement in Defense of Human and Civil Rights), but the left-leaning KOR (Workers' Defense Committee) - the most influential dissident group - also engaged in the celebrations, organizing "the unveiling of a plague in honor of Piłsudski at the Church of St. Aleksander in Warsaw." 86

In 1980, during a period of relative freedom known as the "Festival of Solidarity," the Independence Day celebrations were the largest since the late 1940s. According to the estimates of the Secret Police, around 40,000 people participated in various events across the country. About 10,000 people participated in the ceremony at the Tomb of the Unknown Soldier in Warsaw. On 13 December 1981, Solidarity was delegalized, but it continued to pressure the communist regime through a myriad of clandestine and overt actions, including various efforts to

${ }^{82}$ See A. Stawarz, "11 listopada w Polsce niesuwerennej i suwerennej," n.d., http://www.muzeumpilsudski.pl/swieto-niepodleglosci/11-listopada-w-polsce-niesuwerennej-i-suwerennej (accessed 19 November 2017).

${ }^{83}$ Biskupski, Independence Day, 121.

${ }^{84}$ As Biskupski demonstrates, there were some attempts to commemorate 11 November already in 1956 (Independence Day, 124).

85 "In reality, 1978 marked the unofficial resurrection of November $11^{\text {th }}$ as Polish Independence Day. Not since World War II was so much attention devoted to the date and the events and people associated with it. Virtually every segment of Polish society was somehow involved in the recollection of November $11^{\text {thy }}$ (Biskupski, Independence Day, 133).

${ }^{86}$ Biskupski, Independence Day, 133. 
celebrate 11 November until the final fall of the system in 1989. On the other hand, the communists, clearly aware of their weak and dwindling legitimacy, were gradually intensifying the cultural hybridization strategy whereby they attempted to prop up their regime by combining national and international socialist motifs in their symbolic displays and performances, including the official celebrations of 11 November. ${ }^{87}$

The dissident celebrations of the Independence Day (11 November) in the Polish People's Republic did undergo a remarkable evolution. The $60^{\text {th }}$ anniversary celebrations of 1978 were a game changer. They were relatively large and communicated that the opposition was committed to the struggle for national sovereignty and independence from the Soviet Union. ${ }^{88}$ The symbolism was austere and simple; the cult of Piłsudski and the celebration of his ideas were dominant. The key national symbols - the national flag and the (often re-crowned) White Eagle with their narrow intension and thus broad extension referenced a multi-vocal image of the Polish national community. This is evidenced by the fact that dissidents of all persuasions, from the left to the right, participated in the events and helped to organize them. ${ }^{89}$ The message was populist in the sense of advancing a strong polar division between the "good people" and the "bad authorities." Its tone was not directed against a societal other (for example, an ethnic group) but a political alien, the communist rulers and their Soviet sponsors, whose dominance over Poland was symbolically rejected.

In 1989 Independence Day returned to the official ceremonial calendar, following its restoration on 15 February 1989 by an act of the Parliament still controlled by the communists. The first official ceremony, held in Warsaw already after the fall of communism, was largely spontaneous and its tone unmistakably Piłsudskiite. Held in the Józef Piłsudski Square, freshly so renamed, ${ }^{90}$ the event included the unveiling of a plaque commemorating Marshal Piłsudski in the

87 "By 1988, however, the Jaruzelski government adopted a final desperate strategy to save the regime. It capitulated to the November $11^{\text {th }}$ - Piłsudski nexus it had been intermittently embracing and combating for more than two decades. November $11^{\text {th }}$ and the whole symbolic paraphernalia of Piłsudski were no longer to be suppressed but to be assimilated." (Biskupski, Independence Day, 147).

${ }^{88}$ This goal, shared by all dissident groups, was however differently prioritized. It was more pronounced in the programs of KPN and ROPCiO, less in the ideology of KOR.

${ }^{89}$ Biskupski, for example, begins his analysis of various organizations with KOR, usually seen at the left end of the dissident political spectrum. See Biskupski Independence Day, 133-5.

${ }^{90}$ Piłsudski's statue was unveiled at the edge of the Square on 14 August 1995. 
presence of his granddaughter, ${ }^{91}$ with a band performing "We the First Brigade," a marching song of his legions, heard in the People's Republic only in unofficial settings.

In the following years, National Independence Day became the most important state holiday. ${ }^{92}$ The festivities were multifaceted, with solemn and carnivalesque tones intermixed. Solemnity came from the dominance of the official, state-centered celebrations (Fig. 6). The carnivalesque elements included parades of reenactors and - most spectacularly - Piłsudski's return to Poland in 1918, in which a popular actor assumed the role of the Marshal. In Warsaw, a typical scenario of the two-day event would include all or some elements from the list we take from the official account of the particularly imposing $90^{\text {th }}$ anniversary celebrations in $2008 .{ }^{93}$ That year, about 800 guests, domestic and foreign, including 16 heads of governments, arrived in Warsaw. The events included: (1) Catholic Masses (most prominently the official mass "For the Fatherland"); (2) the official state celebration, led by the President on Piłsudski Square, including a changing of the guard, a roll call of war heroes, and a military review at the Tomb of the Unknown Soldier; (3) a reenactment of Piłsudski's return to Warsaw; (4) laying of wreaths at the Piłsudski statue; (5) a military parade; (6) a parade of reenactors wearing historical costumes; (7) a state gala concert presided over by the President; and (8) the President's announcement of officer promotions and awarding of military orders. In sum, the celebrations, extending over two days, were characterized by organizational and symbolic heterogeneity and a pronounced historicizing theatralization, yet with the dominance of the official - Piłsudskiite in tenor - state ceremonial.

91 "Józef Piłsudski (1867-1935), statesman, Marshal of Poland, incarnation of the desire for independence, creator of the Legions, first Chief of State, victorious commander in the war with Bolshevik Russia." See Biskupski, Independence Day, 157.

${ }^{92}$ W. Szacki, "11 listopada najważniejszy," Gazeta Wyborcza, 21 November 2008, http://wyborcza.pl/1,75398,5901056,11_listopada_najwazniejszy.html (accessed 9 December 2017). See also Biskupski Independence Day, 165; CBOS, "Święto Niepodległości," Komunikat z Badań BS/168/2008 (Warsaw: CBOS, 2008).

${ }^{93}$ Senat Rzeczypospolitej Polskiej, "Wydarzenia 11 listopada 2008," n.d., http://senat.gov.pl/diariusz/wydarzenia/art,1040,11-listopada-2008-r-.html (accessed 10 December 2017). 


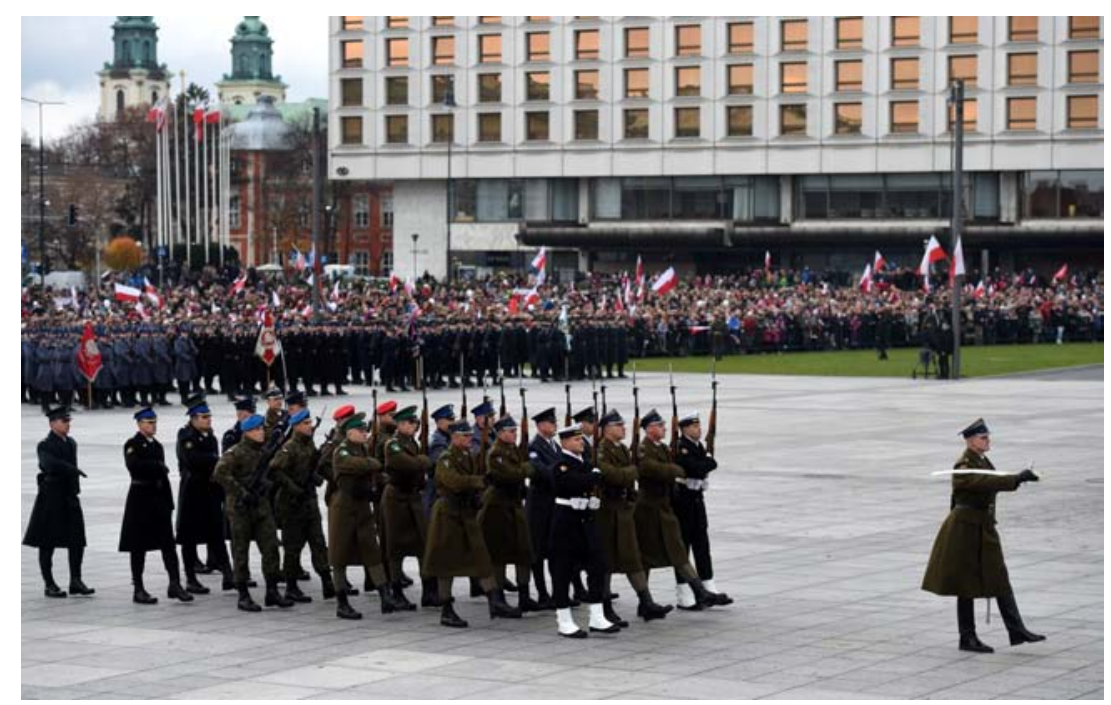

[Fig. 6. The state-centered celebrations of 11 November in 2015, the Piłsudski Square, Warsaw. Copyright Radek Pietruszka / PAP]

Along the way, however, the manner of celebrating changed as far-right rallies and marches were gaining popularity, attracting publicity, and growing in numbers. This process accelerated after the unveiling a statue of Dmowski on Warsaw's Rozdroże Square on 10 November $2006 .{ }^{94}$ The symbolic space of Warsaw acquired a powerful marker whose presence created a new opportunity to invigorate the Dmowskiite tradition, narrowly nationalistic in tone by contrast to Piłsudskiite open patriotism. As other observers also noted, 2006 constitutes a critical juncture after which the game of symbolic politics in Poland changed, with the far-right narratives and performances acquiring new visibility. ${ }^{95}$ At their core were ceremonial invocations of extreme nationalism increasingly intertwined with the nationalized version of Polish Catholicism. By 2017, both narratives were tightly coupled, as the massive nationalist March of Independence in Warsaw was organized under the slogan "We Want God."

The March of Independence grew out of the initially small and somewhat improvised events, organized by far-right organizations whose visibility in the public space was increasing

94 “Odsłonięto pomnik Romana Dmowskiego,” 10 November 2006, https://wiadomosci.wp.pl/odslonieto-pomnik-romana-dmowskiego-6037524950385281a (accessed 9 December 2017).

${ }^{95}$ See, for example, Płatek and Płócienniczak, "Mobilizing on the Extreme Right." 
over time. In 2006, the National-Radical Camp (Obóz Narodowo-Radykalny - ONR) ${ }^{96}$ marched through Warsaw, with a route leading from the Royal Castle to the Dmowski statue. ${ }^{97}$ The event was relatively small-scale, but the following year new groups joined in. The slogans that year included: "God, Honor, Fatherland," "We, a New Generation of Poles," and "All Poland only White and Red." In 2008 on the 90th anniversary of Polish independence, a radical right-wing organization, All-Polish Youth (Młodzież Wszechpolska - MW), ${ }^{98}$ joined ONR and together they "staged a minor demonstration calling for a Catholic Poland and the return of Wilno and Lwów" "99 that was however overshadowed by the spectacular gamut of official celebrations described earlier. In 2009 they marched again under the slogan of national pride, attracting a somewhat larger crowd, but not exceeding a few hundred.

The first March of Independence was organized by MW and ONR in 2010. It seems it did not have yet an official slogan. There are no precise estimates of its size, but judging by the available video materials, the event was considerably larger than the rallies and demonstrations of the previous years - while earlier participation was counted in hundreds, in 2010 it seems to have reached thousands of supporters of right wing groups, including a sizable contingent of football fans. ${ }^{100}$ Several major right-wing politicians, journalist and intellectuals endorsed the March and participated in it. ${ }^{101}$ From 2006 to 2010 , the right side of civil society intensified its performances

${ }^{96}$ Today's ONR continues the tradition of the National Radical Camp, an extreme right-wing organization formed in 1934. For a brief introduction to the history of Polish radical right and its contemporary activities, see R. Pankowski and M. Kornak, "Radical Nationalism in Poland: From Theory to Practice," in Right-wing Extremism in Europe: Country Analyses, Counter-Strategies and LaborMarket Oriented Exit Strategies, eds. R. Melzer and S. Serafin (Berlin: Friedrich Ebert Foundation, 2013), 157-68. For a typology of Polish radical right groups see D. Kasprowicz, "The radical right in Poland from the mainstream to the margins. A case of interconnectivity," in Transforming the Transformation? The East European Radical Right in the Political Process, ed. M. Minkenberg (London: Routledge, 2015), 157-82.

${ }^{97}$ A. K. Zienkiewicz, "Historia Marszu Niepodległości - 11 lat w marszu," 31 October 2017, https://kierunki.info.pl/2017/10/artur-krzysztof-zienkiewicz-historia-marszu-niepodleglosci-11-marszu/ (accessed 10 December 2017).

${ }^{98}$ See Pankowski and Kornak, "Radical Nationalism."

${ }^{99}$ Biskupski, Independence Day, 170.

${ }^{100}$ RafaVideoart, "11.11.2010 Fights Antifa/ONR/Marsz Niepodległości Warszawa,” Youtube, 4 February 2011, https://www.youtube.com/watch?v=TMQjt2azL-A (accessed 14 January 2018).

${ }^{101}$ There were several violent altercations with counter protestors who organized their own rallies and sit-ins. From 2011 to 2014, the number of violent confrontations, both with the police and counterprotestors, kept increasing. It seems to have been related to the fact that Civic Platform, a party in power 
and started asserting itself in the public space to promote a Dmowskiite vision of national identity. A gradual rebalancing of the organizational composition and symbolic message of the celebrations, from the state to - in this case a specific sector of - civil society, commenced.

By 11 November 2011, MW and ONR created an umbrella organization, the March of Independence Association, which has been organizing the March since then ${ }^{102}$ and shaping its public image by means of official posters, slogans, the website as well as other methods of branding. It is estimated that in 2011 there were around 25,000 participants. The March did not have a slogan, but its official poster showing six young people, four of them wearing uniforms of Polish soldiers from various periods, announces: "A Time of Heroes! Tomorrow Belongs to Us." In 2012, the March was seemingly bigger (estimates vary between 25,000 and 50,000) and the participants marched under the slogan "Let's Reclaim Poland." Three figures dominate the poster. A young woman, wearing national colors and holding the "Szczerbiec" coronation sword, ${ }^{103}$ seems to also have white and red wings. She is accompanied by two "warriors:" a hussar $^{104}$ and a soldier wearing a uniform of the pre-1939 Polish army, used also in the underground (Fig. 7). In 2013, the poster features four young people surrounding an elderly man, most likely a veteran of the Warsaw Uprising. His hand rests on a young woman's shoulder as if to pass on the duty of responsibility for the Fatherland. The poster proclaims: "A New Generation is Coming!"

at that time, was seen as a political adversary by the organizers. After 2015, when PiS, a party sympathetic to the March's cause, came to power, the level of violence went down (as of November 2017). Since our text is focused only on the symbolic transformations of the March's main message, we do not analyze this important dimension here. For year 2011 and 2012, see for example Pankowski and Kornak, "Radical Nationalism,"163-7.

${ }^{102}$ Marsz Niepodległości, "Historia,” n.d., https://marszniepodleglosci.pl/historia/ (accessed 10 December 2017).

${ }^{103}$ Szczerbiec was the coronation sword of Polish monarchs between XIV and XVIII century. It functions in the national iconography as a symbol of Polish power and sovereignty, often adopted by farright nationalist movements and parties, including MW and NSZ (National Armed Forces).

${ }^{104}$ Hussars, an elite and heavily armored Polish cavalry, are broadly believed in Poland to be the decisive factor in the victorious 1583 Battle of Vienna against the Ottomans. 


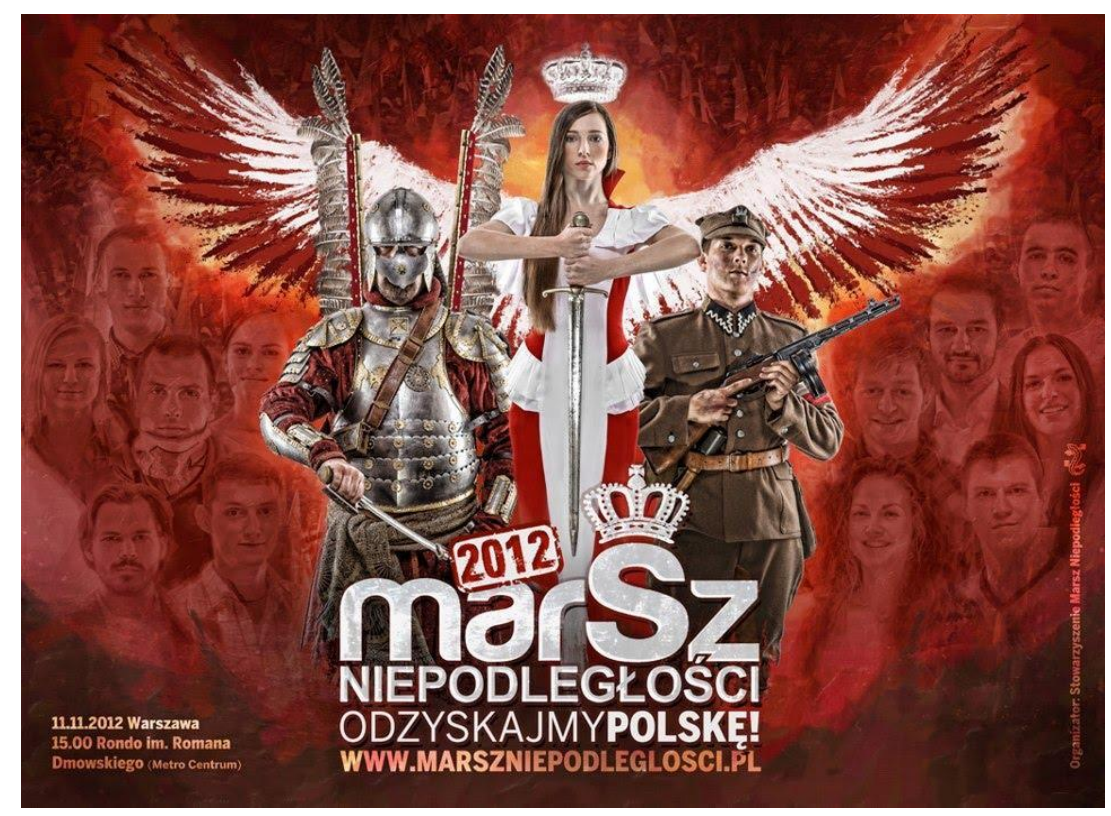

[Fig. 7. Official poster of the 2012 March of Independence. Copyright https://marszniepodleglosci.pl, promotionalmaterials]

In 2014 the tone changes. From now on, the posters feature larger numbers of marching people waving Polish flags, presumably the crowds participating in the March of Independence. They seem to be designed not only to reflect the growing number of participants, but to encourage others to join in. That year's poster declares "The Army of Patriots." The silhouettes of the interwar national leaders appear in the sky above them: Roman Dmowski, Józef Piłsudski, Wincenty Witos and Ignacy Paderewski. In 2015, the poster slogan announces "Poland for Poles - Poles for Poland," making it clear that the March's organizers subscribe to a "thick," exclusionary vision of Polishness without foreigners and are reminding Poles that their chief duty is to serve the Fatherland. The poster features a face of a young woman, her hair adorned with two, white and red, carnations. An eagle's head appears behind her face. The bottom of the poster shows a crowd waving national flags, covered in red smoke from flares, a typical attribute of the militant football hooligan culture.

In 2016 another major theme of the right-wing mythology appears on the poster: Poland as the defender of Christianity. "Poland - the Bastion of Europe," the poster declares as the March's image acquires a decisive militaristic tone. It features a cavalryman, sitting on a horse, portrayed against a cross that is fashioned out of black smoke. A large crowd waving national flags emerges from the cross's horizontal arm. Red smoke hovers above the crowd. Another 
element is a picture of the March, presumably from earlier years, crossing the Poniatowski Bridge in Warsaw. The point seems to be, again, to represent the March as a mass event imbued with militarism. The poster features also relatively large emblems of four organizations involved in the March: MW, ONR, NSZ (National Armed Forces), and the March of Independence Guards (Fig. 8).

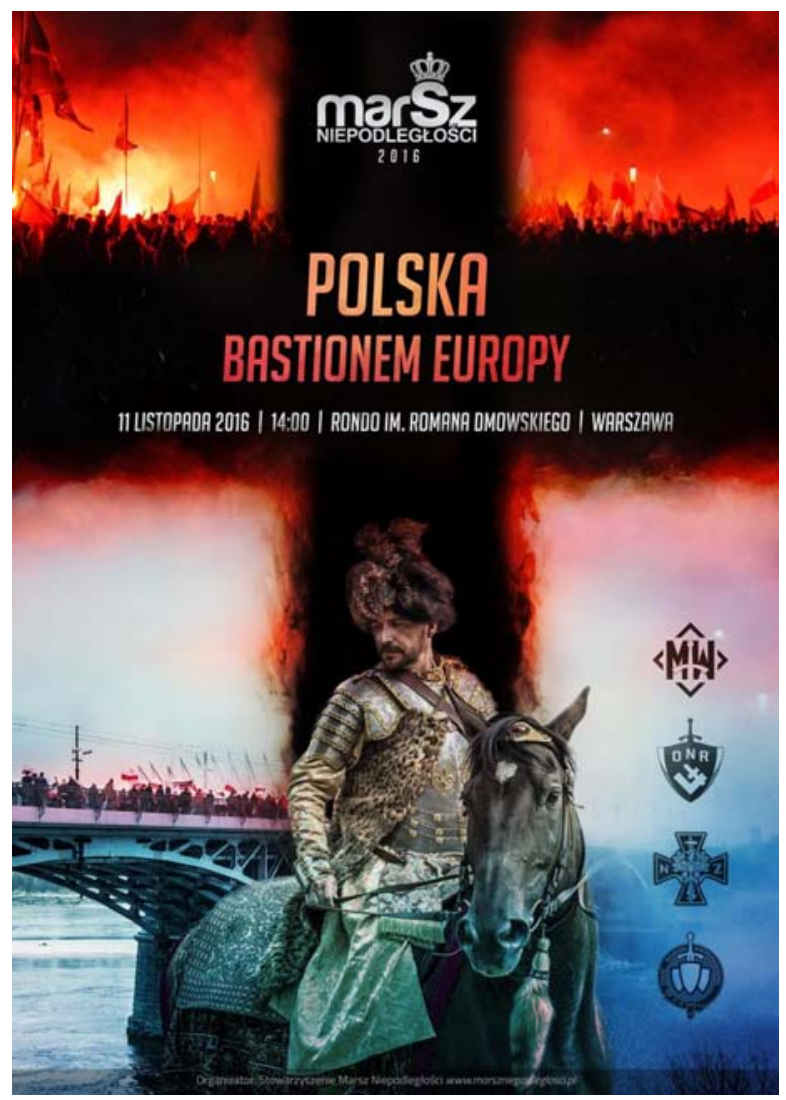

[Fig. 8. Official poster of the 2016 March of Independence. Copyright https://marszniepodleglosci.pl, promotionalmaterials]

The 2017 March was one of the biggest to date and due to its blatant right-wing ideological content attracted a lot of attention around the world. At least 60,000 participants, ranging from families with children to masked white supremacists and militant groups of football fans holding red flares, marched through the streets of Warsaw and took part in a massive rally (Fig. 9). 


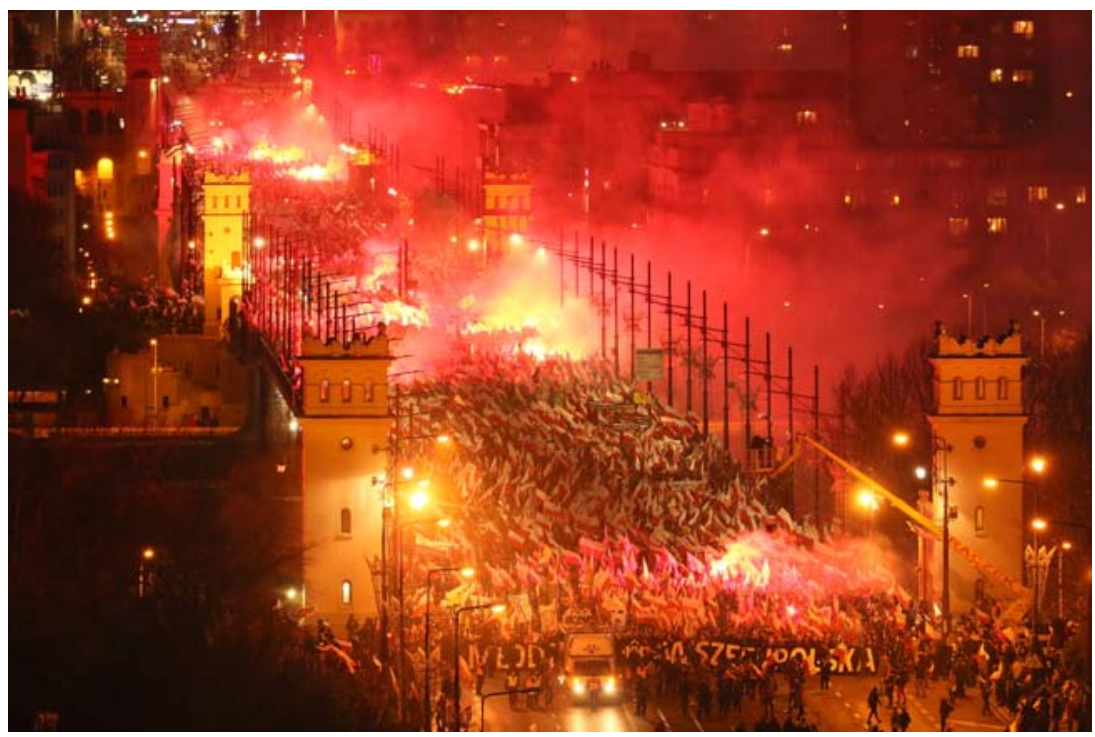

[Fig. 9. The 2017 March of Independence, Poniatowski Bridge, Warsaw, 11 November 2017. Copyright Leszek Szymański / PAP]

The official poster, promoting the event's main slogan, "We Want God," seems to depict the Judgment Day. Its main figure is Saint Michael the Archangel, trampling Satan portrayed as a snake. A patron of right-wing groups and a frequent feature in nationalistic tattoos, he symbolizes the "fight against evil, vice, idolatry and heresy," as an ONR website points out. ${ }^{105}$ Crowds waving Polish flags march through the sky (Heaven?), dominated by the Jerusalem Cross - a symbol associated with the Crusades and the Knights of the Holy Sepulcher. The damned, engulfed by flames, descend to an abyss (Hell?) that has opened in front of the building of the Council of Ministers in Warsaw. To the inscription featured on the actual building's façade, "Honor and Fatherland," the poster's creator added the word "God," replacing the slogan with a version that emphasizes the indispensability of Catholicism in Polish national culture and state affairs (Fig. 10).

${ }^{105}$ ONR Brygada Kujawsko-Pomorska, “Św. Michał Archanioł - Nasz Patron,” 29 September 2017, http://onrkujawy.pl/sw-michal-archaniol-patron/ (accessed 15 January 2018). 


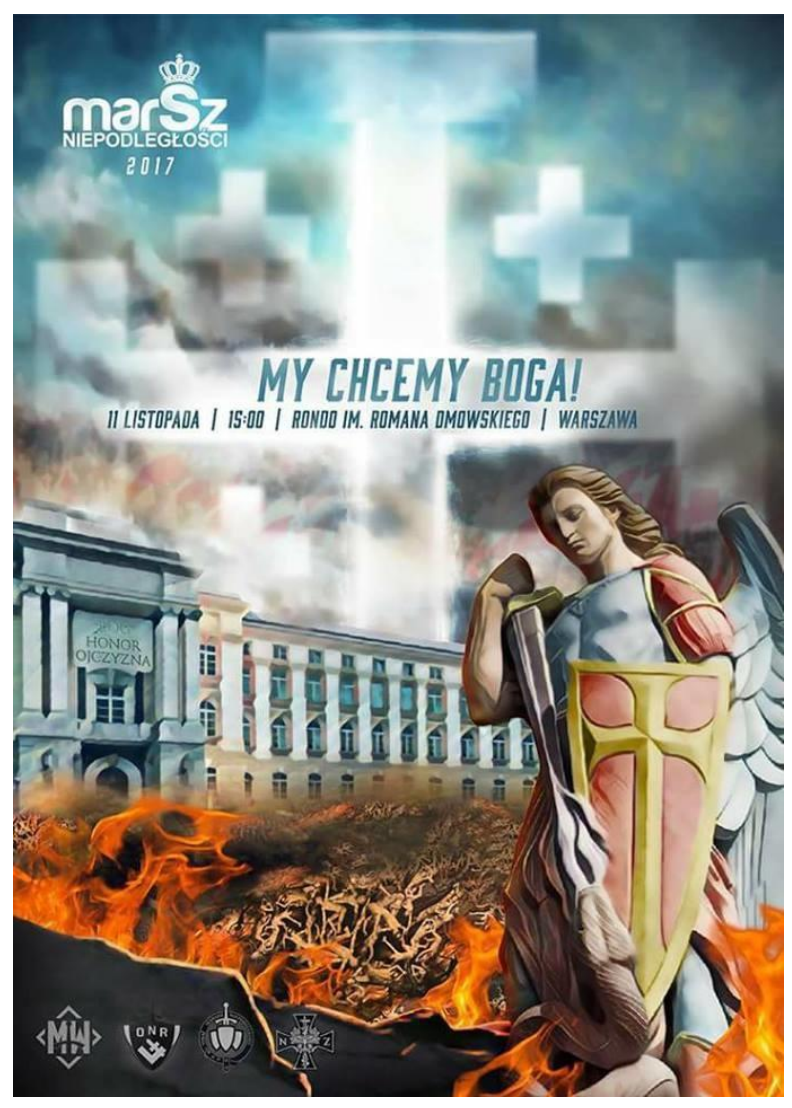

[Fig. 10. Official poster of the 2017 March of Independence. Copyright https://marszniepodleglosci.pl, promotionalmaterials]

The evolving and increasingly complex message of the March of Independence - in the eyes of its organizers "the most popular all-Polish march"106 - has been sharpened over time by the cumulative symbolic thickening of its performative and visual imagery. Year on year, the crowds have been growing and the clouds of red smoke surrounding them thickening. The meanings conveyed in both displays and performative acts are complex but our reading, based predominantly on the analysis of pictures and videos of marching people (including interviews with some of them), posters and selected slogans, suggests a gradually emerging master narrative ${ }^{107}$ of a new, young generation rising to reclaim Poland. They see themselves as true patriots and heirs to a heroic and victorious military tradition ("Death to the Fatherland's enemies!"). They intend to create Poland for Poles, who are to be militantly Catholic, inspired by

${ }^{106}$ Marsz Niepodległości, "Historia."

${ }^{107}$ Limited by the size of this essay, we rely almost exclusively on an iconographical study of the March's posters, as we assume that they reflect accurately and summarize the meaning of the event intended by the organizers. 
the Crusades ("Deus Vult"108), preferably white ("Europe will be white or uninhabited"), heteronormative and socially conservative ("A boy and a girl - a normal family"; "Abortion kills children"), and adamantly anti-communist ("Use a sickle, use a hammer, smash the red rabble"). They are increasingly committed to defending Europe that faces serious threats, internal and external, these days coming particularly from Islam ("Europe wake up" - an inscription on a massive installation depicting Islam as a Trojan Horse) (Fig. 11). All those motifs were present in the 2017 March, making its symbolism particularly thick.

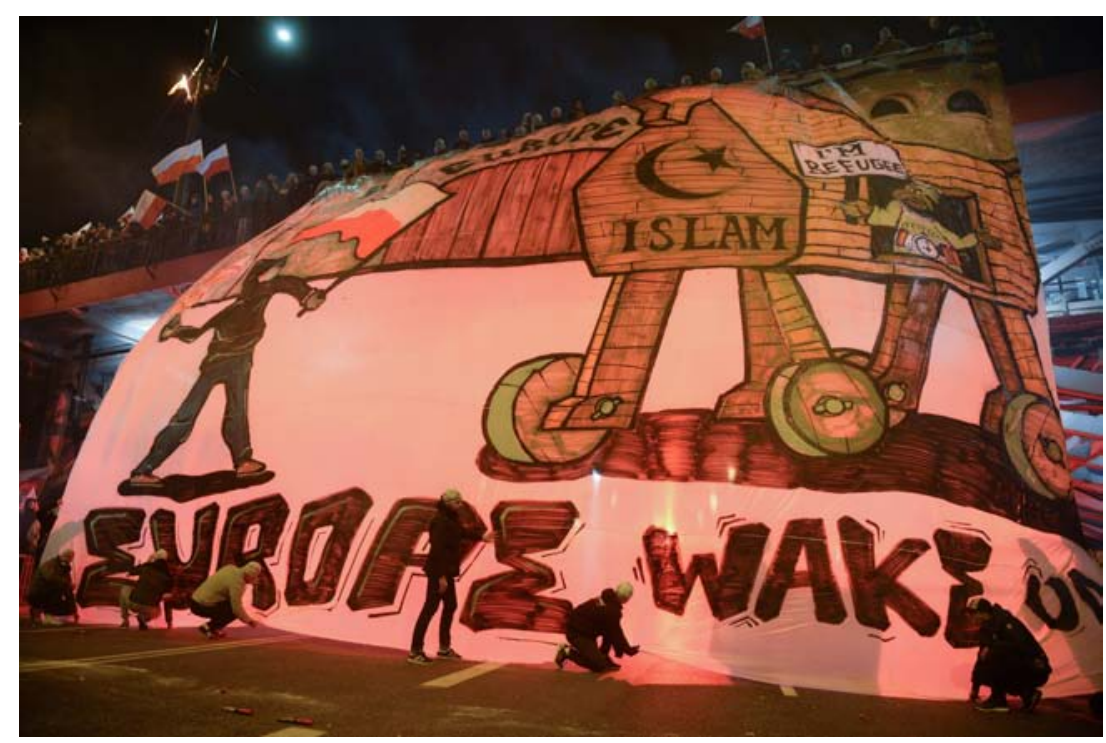

[Fig. 11. Islam as a Trojan Horse, 2017 March of Independence, Warsaw. Copyright Jacek Turczyk / PAP]

From 1989 to 2017, the celebrations of 11 November underwent a remarkable evolution in three dimensions: discursive, organizational, and participatory. Initially, the day was organized around several separate celebrations, some solemn, some festive and somewhat carnivalesque. Discursively, it was a performative mosaic, but the official state ceremonies, full of Piłsudskiite motifs, were setting the tone. The projected vision of the nation was of a political/civic variety, open and friendly to others. Catholic Masses were central, but religious motifs were not pronounced in other events of the day. Gradually, an ideological polarization started

108 "God Wills It!" was a battle cry during the First Crusade in 1095. See Dana C. Munro, "Urban and the Crusaders." Translations and Reprints from the Original Sources of European History, vol 1:2 (Philadelphia: University of Pennsylvania, 1895), 5-8. 
overshadowing the holiday's heterogeneity, as the celebrations staged by the far-right groups, particularly the March of Independence, began setting the tone for the whole day. Given the enormous symbolic elaboration of the March, its sheer size, and the shock-value of its dominant, extreme right-wing message, the media focused on it and the images literally traveled around the world. Most outside observers did not seem to realize that the March was just one element in a full day of ceremonies and festivities.

As Biskupski notes, over the years there were efforts to include a variety of actors in organizing the day's events and shift the focus from the state to the society. This shift was eventually accomplished, as civil society actors, albeit representing its far-right sector, put on the most spectacular and broadly commented symbolic show of the day. As a result, the celebrations of the most popular state holiday in the official's ceremonial calendar no longer signaled that the state fully controls the center of the ritual order in the society. The state's ceremonial monopoly was challenged by the March of Independence Association that promoted an extreme vision of the Polish nation aided symbolically and ideologically by a specific interpretation of Catholicism, centered on the idea of Grand Catholic Poland. In response, PiS and its government equivocated and did not formally distance itself from this radical expression of Polish nationalism; some of its officials, including the President, condemned it, but others either condoned it or reacted with silence. $^{109}$

The manner of participation also evolved. Initially, while the celebrations were dominated by the state-led grandiose military parades and the solemn changing of the guards at the Tomb of the Unknown Soldier, most people participated as passive spectators. Some participated as reenactors, whose actions would invoke and reference specific historical events or personages. The principal mode of engagement in the March is, by contrast, immersive. Every participant takes part in constructing its meaning. And the task does not seem to be designed to reconstruct the meaning of specific historical events, as in reenactments, and thus to help people to establish a genealogy to ensconce their identities in some "comforting" fragment of the past. Instead, the

${ }^{109}$ See, for example, J. Noch, “Andrzej Duda nie odpuszcza organizatorom Marszu Niepodległości. Nie będą współorganizowali przyszłorocznego święta,” Na Temat, 20 November 2017, https://natemat.pl/223269, andrzej-duda-nie-odpuszcza-organizatorom-marszu-niepodleglosci-nie-bedawspolorganizowali-przyszlorocznego-swieta (accessed on 26 August 2018) and "'Proszę nie ulegać jednoznacznym skojarzeniom.' Błaszczak o 'rasistowskich transparentach' na Marszu Niepodległości," Polsat News, 11 November 2017, http:/www.polsatnews.pl/wiadomosc/2017-11-11/blaszczak-swietoniepodleglosci-przebiegalo-w-bardzo-dobrej-atmosferze-bylo-bezpiecznie/ (accessed 26 August 2018). 
meaning-creators work together to invoke a specific albeit totalizing mythology of the national past to gain control over the present, also its political aspect. It is a cultural strategy in which, in Appadurai words:

The past is now not a land to return in a simple politics of memory. It has become a synchronic warehouse of cultural scenarios, a kind of temporal central casting, to which recourse can be had as appropriate, depending on the movie to be made, the scene to be enacted, the hostages to be rescued. ${ }^{110}$

The evolution of the celebrations of 11 November is an example of symbolic thickening, as the propagated image of Polishness (the chief defining attribute of "the people"), initially "thin" for signified via a heterogeneous set of solemn and festive events, was gradually narrowed. This happened as one specific vision of national identity - the intensely nationalistic PoleCatholic model - achieved unprecedented prominence in public culture, partially due to the sheer performative force of the March of Independence. By performing this narrow version of Polishness, which excludes many types of societal others, the March organizers contributed to the expansion of the discursive opportunity structure for themselves and other right-wing populist movements. They could also claim growing legitimacy ${ }^{111}$ by pointing out the systematically increasing numbers of participants.

Constraints of our methodology and the scope of this essay do not allow us to discuss various motivations driving the event's participants - however, we can offer a few tentative observations. On the one hand, our analysis of the performative side of the event shows that the actors who are responsible for the ideological and symbolic tenor of the March are its organizers. The event's carefully designed image and publicity, such as the posters, leave little doubt about the version of Polishness the organizers identify as desirable. They are joined by members of various interest groups (such as Catholic pro-life activists) and subcultures (such as hooligans)

${ }^{110}$ A. Appadurai, Modernity at Large: Cultural Dimensions of Globalization (Minneapolis: University of Minnesota Press, 1996), 30.

${ }^{111}$ As we are submitting the last version of this essay, the legitimacy of the March was dramatically strengthened due to exceptionally high attendance at its 2018 edition as well as a change of its status - the President and the government became co-organizers of the event on the $100^{\text {th }}$ anniversary of Polish independence. For a description and analysis of the 2018 March, see our blog post: https://blogs.ucl.ac.uk/ssees/2019/01/23/playing-with-fire-the-2018-march-of-independence-in-warsawas-a-ritual-of-national-identity-building/. 
who perceive the March as an opportunity to voice their sentiments and views that had been often marginalized during the two-term rule of the pro-European Civic Platform. On the other hand, among all celebrations of 11 November the March is unique in offering an opportunity for immersive participation in a performance associated with the Polish traditional patriotism. Thus the March attracts not only ideologically active and often extremist adherents of far-right groups, but also crowds of traditionally-minded families and individuals. We do not know how they define their Polishness, but their participation seems to indicate at least a tacit approval of the definition proposed by the organizers. In several expressions of support for the March, PiS government spokespersons invoked the participation by the latter group, avoiding references to the extreme visions of the organizers.

\section{Conclusions}

In Negara, a masterful essay on the cultural dimension of statecraft, Geertz examines the pomp and ceremony of the nineteenth-century Balinese state. In Bali the officials put on a theater show in which actors' performance produced images designed to solidify the state's legitimacy. ${ }^{112}$ By contrast, in the 2010s the Polish state provided a theater stage on which nonstate cultural entrepreneurs, far-right populists most prominently, performed spectacular dramas, sometimes resorting to violence, clashing with the police, and propagating their own exclusionary vision of national identity. This vision was more extreme than the traditionalist version of Polishness championed by PiS and its government since 2015. Furthermore, being inevitably at odds with the liberal-conservative ideology, supported by a substantial portion of the population and advocated by PO, the main opposition party, its articulation exacerbated the Polish war of symbols over the meaning of such cultural fundamentals as Polishness, the tenor of the national religion (Catholicism) or the norms of civic coexistence.

This war has been a long time in brewing, fueled by the growing political power of populism, mostly of right-wing variety, and the rightward turn in several areas of public culture. As the most recent research demonstrates there are many factors that in various combinations can

${ }^{112}$ C. Geertz, Negara. The Theatre State in Nineteenth-Century Bali (Princeton: Princeton University Press, 1980). 
explain such a change. ${ }^{113}$ Some of them are economic, some political, others cultural. In Poland, however, economic factors do not seem to have played a prominent role in the process that eventually brought right-wing populists to power. Prior to their emergence as a serious political contender, the economic situation in the country was about the best among the post-communist states ${ }^{114}$ and yet in none of them, with the exception of Hungary, right-wing populists came to power, although there are of course regions of relative poverty and economic dislocation. It is important to note, however, that in 2015 populist parties achieved successes way beyond such areas. $^{115}$

Since the economic explanation is insufficient, the principal causes of the populist success in Poland are to be found most likely among political and cultural factors interacting with economic factors and each other in what is best characterized as a circular cumulative causation. Determining whether the decisive push for right-wing populism came from politics or culture is impossible without a detailed reconstruction of a longer historical process at least since 1989. Such a task is beyond the scope of this essay, but the basic elements of both political and cultural processes are known.

On the political side, several populist formations engaged in diligent organizational work in both the civic and political spheres and eventually emerged as viable contenders for power, one of them, PiS, winning the elections of 2015 and forming the government. ${ }^{116}$ There were several critical junctures in this process. The first, arguably the most consequential, came in 2001 when three populist formations, PiS, Self-Defense (Samoobrona RP), and The League of Polish Families (Liga Polskich Rodzin) won enough votes to enter the Parliament. ${ }^{117}$ They found most

${ }^{113}$ C. Rovira Kaltwasser, P. Taggart, P. Ochoa Espejo and P. Ostiguy, eds., The Oxford Handbook of Populism (Oxford: Oxford University Press, 2017).

${ }^{114}$ G. Ekiert and G. Soroka "Poland," in Pathways to Freedom, Vol. 21 (New York, NY: Council on Foreign Relations, 2013), 77-104.

${ }^{115}$ M. Wojtalik, "Wyniki Wyborów: PiS Przejmuje Polskę, a Prawica Młodzież,” Newsweek Polska, October 26, http://www.newsweek.pl/polska/szczegolowe-wyniki-wyborow-parlamentarnych2015-jak-glosowaly-wojewodztwa,artykuly,372966,1.html (accessed on 15 January 2018).

${ }^{116}$ As Płatek and Płócienniczak convincingly demonstrate the extreme right mobilization progressed through three stages since 1989. See D. Płatek, and P. Płócienniczak, "Mobilizing on the Extreme."

${ }^{117}$ B. Stanley, "Down With the Pseudo-Elite! Populism as a Strategy for Elite Replacement in Post-Communist Poland," conference paper, IPSA, n.d., http://paperroom.ipsa.org/papers/view/16004 (accessed on 5 August 2018). See also A. Szczerbiak (2002) "Poland's Unexpected Political Earthquake: 
of their electoral support among the people who had been already culturally mobilized by rightwing media and clubs, most prominently perhaps by Radio Maryja. ${ }^{118}$ The second juncture was the election of 2005, when a coalition of three right-wing populist parties, PiS, Self-Defense and LPR won enough votes to form the government. The coalition survived for only two years and after it lost power the right-wing populists had to wait until 2015 to win again. In the meantime the field of populist forces was gradually becoming dominated by PiS and growing in strength despite conflicts and fragmentation. ${ }^{119}$

On the cultural side, the process involved the intensifying ideological campaign and cultural mobilization by right-wing populists of various hues, ranging from cultural clubs and youth sections of right-wing populist parties to far-right associations and football hooligan clubs. Other actors, with less explicit political agendas but with palpable determination to redefine public culture, included several circles of conservative intellectuals, a significant segment of the Catholic clergy, some Catholic media (Radio Maryja most prominently), and a few lay Catholic organizations. In this essay we offer an interpretation of a cultural mechanism we believe is central to the whole process: an iterative interaction between the symbolic thickening of public culture, and the ideological thickening of populism. We focus on symbolic thickening transpiring in subcultures infused with religious elements, where we observe the interrelated intensification of exclusionary Catholicism and assertive nationalism that results in the expansion of the discursive opportunity structure for right-wing populists who utilize religious motifs in their ideologies. Simply put, being surrounded by an increasingly "thick" public culture they found it much easier to plan and execute what Pytlas and Kossack call a narrative (rightward) shift and we

The September 2001 Parliamentary Election," The Journal of Communist Studies and Transition Politics 18, no. 3 (2002): 41-76. Pankowski writes: "The Polish extreme right was almost completely insignificant in the mainstream political arena until 2001. By that time, however, it had developed sizeable cultural bases and pockets of social legitimacy that could be used to build political organizations. These cultural resources proved very useful in allowing nationalist populism to enter the political mainstream in 2001, when it won its first parliamentary seats, and even more profoundly in 2005 when it came to dominate the Polish political landscape." See R. Pankowski, "Identity and bigotry: Nationalist populism and the extreme right in contemporary Poland," in Is Europe on the "right" path? Right-wing extremism and right-wing populism in Europe, ed. N. Langenbacher and B. Schellenberg (Berlin: Friedrich-EbertStiftung 2011), 209.

${ }^{118}$ Stanley, "Down With the Pseudo-Elite!," 12, and B. Stanley, "Defenders of the Cross."

${ }^{119}$ Kasprowicz provides a systematic catalogue of populist parties and movements in Poland and reconstructs frequent recombinations of their alliances. See D. Kasprowicz, "The radical right." 
refer to as the ideological thickening of populism. ${ }^{120}$ The emergent ideological and cultural climate improved opportunities for enhancing the legitimacy of populist movements and parties. ${ }^{121}$ The rising legitimacy and popularity of the increasingly vigorous right-leaning "thick" populism, in turn, contributed to the further symbolic thickening of public culture.

There are many instances of the intensifying religious thickening of Polish public culture, but the "Rosary to the Borders" is one of the most spectacular. This massive ritual helped to reinforce a specific understanding of Polishness, as the key attribute of "the people" who defend their specific collective identity (deeply nationalistic and ardently Catholic), but are also ready to go on a mission to re-Christianize Europe, armed with their rosaries. This understanding underpins the political program espoused by the ruling party, PiS, whose strongly populist ideology serves to legitimize their attacks on the institutions of the liberal-democratic order. In addition to expanding the discursive opportunity structure for the more "traditionalistic" and right-wing political actors, "Rosary" and similar rituals normalize the magical mode of engagement with the world, raising doubts about pragmatic, task-oriented politics.

To illustrate the mechanism of symbolic thickening we chose to study the change of meaning of the Poznan Monument. While the case is as simple as it can get (two words added to the inscription), it illustrates well the religionization of public culture and the resulting expansion of the discursive opportunity structure, for those political actors who want to promote religious ideas or have strong religious elements in their ideologies. ${ }^{122}$

A detailed analysis of the celebrations of the Independence Day, 11 November, from their inception in 1937 to 2017, illustrates the symbolic thickening of public culture through three dramatic shifts in the meaning of the central Polish holiday. First, the more open, multi-ethnic understanding of Polish national identity associated with Piłsudski was gradually replaced with

${ }^{120}$ B. Pytlas and O. Kossack, "Lighting the Fuse."

${ }^{121}$ For other analyses of this interaction between political and cultural processes see Płatek and Płócieniczak, "Mobilizing on the Extreme Right," and J. Kajta, "Discursive Strategies." She writes: "Both discursive and political opportunities now seem to be favorable for nationalist mobilization. Firstly, we observe a more general radicalization of the public discourse, including the spread of hate speech" (90).

122 'Ferree (2003:306) tells us that 'all discursive opportunity structures are inherently selective,' meaning that some movement frames resonate with critical elements in the larger discursive field, while others do not, because the resonant frames tap into the vocabulary, underlying principles, and narratives of salient discourses in the broader cultural environment." (H. J. McCammon, H. D. Newman, C. S. Muse, and T. M. Terrell, "Movement Framing and Discursive Opportunity Structures: The Political Successes of the U.S. Women's Jury Movements,” American Sociological Review 72, no. 5 (2007): 732). 
the narrower, more intensely nationalistic vision of Polishness preferred by the ideological descendants of Roman Dmowski. Second, the state lost its role as the ritual master; instead it was symbolically assumed by the far-right organizers of the March of Independence. Third, the organizers of the March were gradually strengthening the symbolic link between a radically nationalistic vision of Polishness and a traditionalist version of Catholicism. This link is constructed in a similar manner in the ostensibly apolitical "The Rosary to the Borders," where Poland was portrayed as a Polish-Catholic fortress manned by "soldiers" equipped with a magico-religious weapon of the rosary. In brief, what emerges in Poland is a form of missionary religion tout court, ${ }^{123}$ inseparably intertwined with several varieties of right-wing populism, including that of the ruling party, PiS.

What are the political consequences of all of this? As Fishman argues, the tone of both the "high" symbolic layer of state ceremonial, as well as citizens' everyday cultural-political practices are as important for the quality of democracy as the performance of formal political institutions or the health of the economic underpinning of politics. As a significant part of the ceremonial system, propelled by the increasingly hyperactive right-wing populists, is geared toward generating a deep cultural-political division between the Poles-Catholics and "cosmopolitans," a severe polarization results and the quality of democracy declines. ${ }^{124}$ When such a deepening cleavage is accompanied by the populists' institutional engineering to undermine or destroy the foundations of liberal democracy - as has been the case of Poland since 2015 - creeping authoritarianism results. The opposites of polarization and illiberal disdain for institutions, mutual toleration and forbearance, are the golden virtues of democracy, as has been argued for generations of thinkers going back to Aristotle. ${ }^{125}$ But they are hard to practice in a

${ }^{123}$ Zuquete defines missionary religion as a form of political religion "characterized by a dynamic interaction between charismatic leadership, a narrative of salvation, outsiderhood and ritualization, and the creation of a moral community invested with a collective mission of combating conspiratorial enemies and redeeming the nation from its putative crisis." (J. P. Zuquette, "Missionary Politics - A Contribution to the Study of Populism," Religion Compass 7, no. 7 (2013): 263-71).

${ }^{124}$ J. McCoy, T. Rahman and M. Somer, "Polarization and the Global Crisis of Democracy: Common Patterns, Dynamics, and Pernicious Consequences for Democratic Polities," American Behavioral Scientist 62, 1 (2018): 16-42.

${ }^{125}$ On mutual toleration and forbearance see S. Levitsky and D. Ziblatt, Daniel. How Democracies Die (New York: Crown, 2018). See also A. Craitu, Faces of Moderation. The Art of Balance in an Age of Extremes (Philadelphia: University of Pennsylvania Press, 2016); P. O. Carrese, Democracy in 
system in which symbolically thickened public culture, deeply resonant with at least some strands of Polish Catholicism, continues to provide a discursive opportunity structure that is skillfully used by various populist actors, including the ruling party, Law and Justice, to incite political polarization. As of the moment of this writing (November 2018), the support for PiS has not only not diminished, but arguably increased since its electoral victory of October 2015. This success cannot be fully explained by the party's populist economic program; the cultural-political feedback loop analyzed in this essay provides a critical part of the explanation.

\section{Acknowledgements}

We would like to thank Magdalena Waligórska for inviting us to the conference, "Poland's War of Symbols," held at the University of Bremen in May 2017. This essay grew out of our presentation there. Magdalena and Simon Lewis provided constant intellectual and organizational support, as they led our team towards successful completion of this special section. The second version of the paper was presented at a conference "The End of the Liberal Order? Central, East and Southeast European Populism in Comparative Perspective," held at the Graduate School for East and South European Studies at the University of Regensburg in June 2017 - Ulf Brunnbauer and Martin Schulze Wessel provided a stimulating atmosphere, making it easy to further develop our ideas. Our research and analysis benefited from comments by Paweł Machcewicz, Łukasz Jastrząb, Andrzej Kompa, Mateusz Mazzini, Agnieszka Pasieka, and Rūta Valaitytè. Participants in two seminars, at Harvard's Center for European Studies (thank you, Grzegorz Ekiert) and Rutgers' Emerging Trends in Political Science Seminar (thank you, Jack Levy), provided incisive criticisms. Chris Holland and Ankur Paul offered indispensable advice on editorial and copyrights matters. Our special gratitude is reserved for the two anonymous reviewers for this journal and its editors. They pushed us with their insightful comments and the final product is hard to imagine without their guidance.

The research Marta Kotwas conducted for this project was partly supported by the Economic and Social Research Council [grant number ES/P000592/1].

Moderation: Montesquieu, Tocqueville, and Sustainable Liberalism (New York: Cambridge University Press, 2016). 